ESCOLA DE ENFERMAGEM DE RIBEIRÃO PRETO

RISCO AMBIENTAL E O GERENCIAMENTO DE RESÍDUOS NOS ESPAÇOS DE UM SERVIÇO DE SAÚDE NO CANADÁ:

UM ESTUDO DE CASO

Angela Maria Magosso Takayanagui

Ribeirão Preto

2004 


\title{
RISCO AMBIENTAL E O GERENCIAMENTO DE RESÍDUOS NOS ESPAÇOS DE UM SERVIÇO DE SAÚDE NO CANADÁ: UM ESTUDO DE CASO
}

\begin{abstract}
Tese apresentada à Escola de Enfermagem de Ribeirão Preto da Universidade de São Paulo para inscrição no concurso para obtenção de título de Professor Livre Docente, Referência MS-5, em Regime de Dedicação Integral à Docência e Pesquisa - RDIDP, junto ao Departamento de Enfermagem Materno-Infantil e Saúde Pública na Área de Ecologia Aplicada à Saúde nas Disciplinas: ERM-127: Introdução à Saúde Pública, ERM-5708: Ecologia e Saúde e ERM-5741: "Gerenciamento de Resíduos Perigosos e Saúde".
\end{abstract}


Autorizo a reprodução e divulgação total ou parcial deste trabalho, por qualquer meio convencional ou eletrônico, para fins de estudo e pesquisa, desde que citada a fonte.

\section{FICHA CATALOGRÁFICA}

Takayanagui, Angela Maria Magosso

Risco ambiental e o gerenciamento de resíduos nos espaços de um serviço de saúde no Canadá : um estudo de caso. - Ribeirão Preto, 2004.

83 f. : il. ; $30 \mathrm{~cm}$.

Tese (Livre Docência) apresentada à Escola de Enfermagem de Ribeirão Preto da Universidade de São Paulo para inscrição no concurso para obtenção de título de Professor Livre Docente, Referência MS-5, em Regime de Dedicação Integral à Docência e Pesquisa - RDIDP, junto ao Departamento de Enfermagem MaternoInfantil e Saúde Pública.

1. Resíduos de serviços de saúde. 2. Gerenciamento de riscos. 3. Gerenciamento de resíduos. 4. Saúde ambiental. I. Título. 
Mamãe, Osvaldo, Alexandre, Talita e Pedro Uma obra nunca é resultado de uma ação solitária. Mesmo que feita a duas mãos, tem sempre alguém torcendo para que ela se concretize. $\mathcal{E}$ vocês, com certeza, são também 'autores' desta obra, que ora finalizo. Minha eterna gratidão pela força e amor. 


\section{Agradecimentos}

Ao Prof. Dr. John Eyles, pelos valiosos ensinamentos e pela confiança em mim depositada.

À Profa. Dra. Susan Elliott, pelo exemplo de pesquisadora e pelo apoio e incentivo recebidos.

A Helen e Elizabeth Waters, pelo carinho e amor com que me receberam, em especial a Elizabeth pelas inúmeras Canada Letters with environmental news.

À Profa. Dra. Maria das Graças B. de Carvalho, pelo apoio e incentivo e pelas valiosas sugestões, feitas com competência e acurada leitura.

Aos Colegas da Área de Saúde Pública, pelo apoio para realização do meu estágio no Canadá.

Agradeço, também, a todos que vêm colaborando comigo nessa minha jornada acadêmica, em especial a FAPESP, pelo Auxílio recebido. 


\section{SUMÁRIO}

\section{RESUMO}

SUMMARY

RESUMÉN

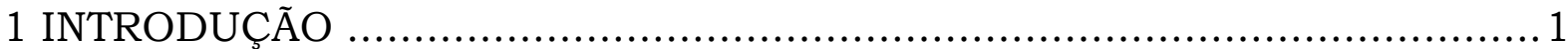

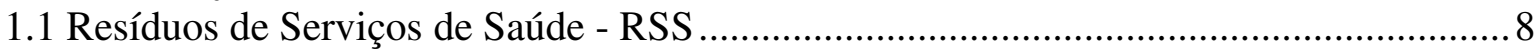

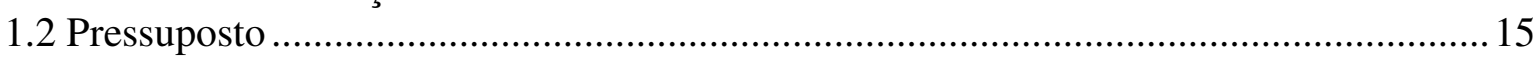

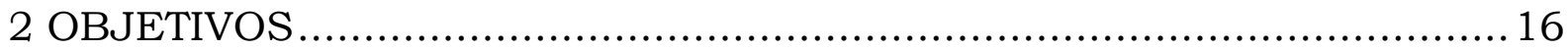

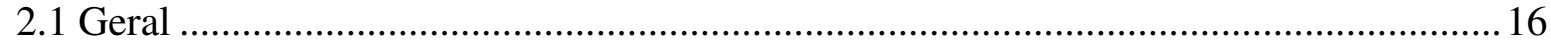

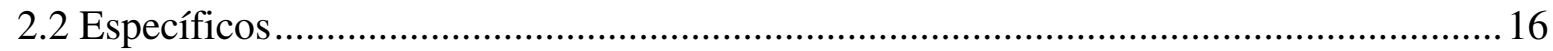

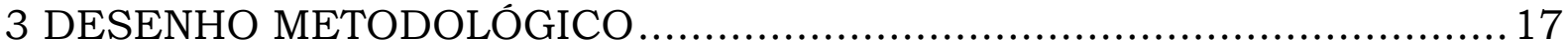

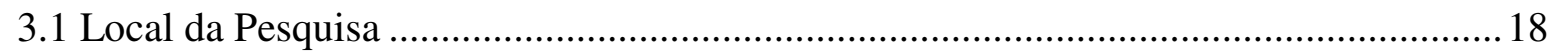

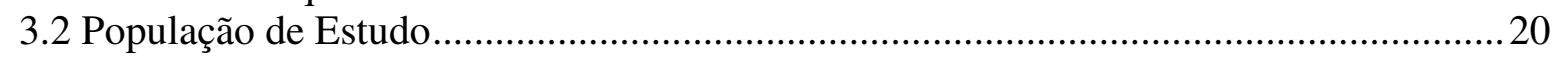

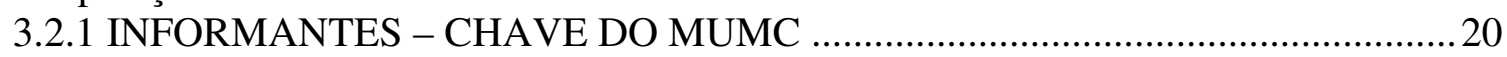

3.2.2 INFORMANTES - CHAVE EXTERNOS AO MUMC ...................................... 21

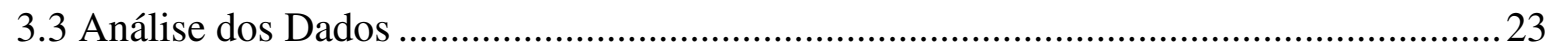

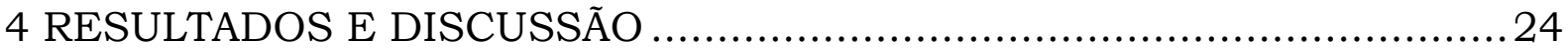

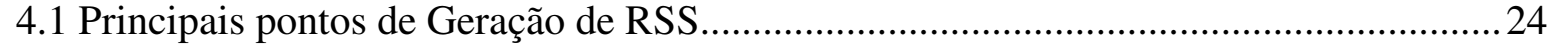

4.2 Os Resíduos de Serviços de Saúde do MUMC …...........................................................29

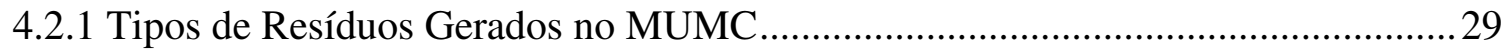

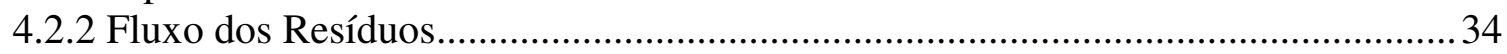

5 CONSIDERAÇÕES FINAIS ...................................................... 42

5.1 Protocolo para Avaliação de Risco por RSS .............................................................. 50

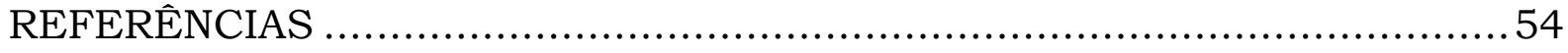

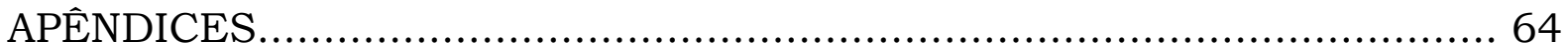

APÊNDICE A Protocolo para Avaliação de Risco de Exposição por Resíduos gerados em

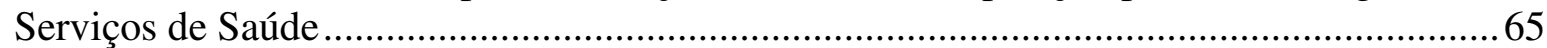
APÊNDICE B Protocolo para Avaliação de Risco de Exposição por Resíduos Gerados em

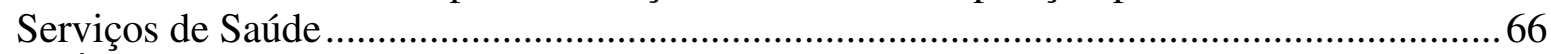
APÊNDICE C - Tipos de Resíduos Produzidos no McMaster University Medical Centre MUMC, em ordem decrescente de volume gerado, e de acordo com as diferentes áreas geradoras - Canadá, 2000.

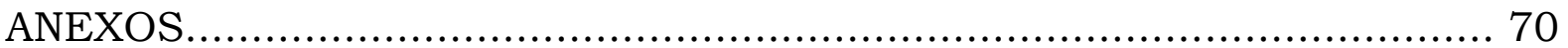

ANEXO A Consent Form for Attend to Environmenta and Health Study …..................... 71

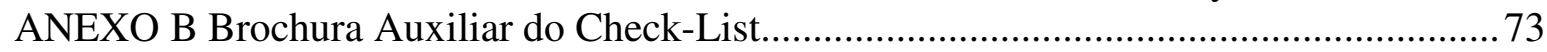




\section{RESUMO}

TAKAYANAGUI, AMM. Risco ambiental e o gerenciamento de resíduos nos espaços de um serviço de saúde no Canadá - um estudo de caso. 2004. 83 f. Tese (Livre Docência) Escola de Enfermagem de Ribeirão Preto, Universidade de São Paulo, Ribeirão Preto, 2004.

Os impactos ambientais causados pelos resíduos sólidos urbanos representam uma das principais questões para os administradores públicos, pelos riscos à saúde e ao ambiente. Dentre esses resíduos, destacam-se aqueles gerados em serviços de saúde (RSS) que, apesar de representarem cerca de $2 \%$ em relação ao total de resíduos urbanos, trazem risco por possuírem agentes biológicos, químicos e/ou radioativos em parte de seu volume gerado. Diferentemente do que ocorre em países desenvolvidos, no Brasil o gerenciamento dos RSS ainda não está de acordo com as recomendações encontradas em realidades mais desenvolvidas, tanto em relação ao seu manuseio, quanto ao tratamento e destinação final. Esta investigação visou conhecer e descrever a estrutura do gerenciamento dos RSS produzidos no McMaster University Medical Centre - MUMC, no Canadá, com vistas à implementação de novas estratégias metodológicas a serem aplicadas à realidade brasileira, na tomada de decisão em processos de avaliação e gerenciamento de risco ambiental. Nosso pressuposto era baseado na similaridade da situação de manuseio e descarte dos RSS, pelos geradores, em relação à situação existente no Brasil, apesar do nível mais desenvolvido de organização legal e condições técnico-operacionais e políticas do Canadá. Esta é uma pesquisa descritiva e exploratória, constituindo-se em um estudo de caso, baseado em entrevistas semi-estruturadas, em observação sistematizada e em um check-list. Os sujeitos contituíram-se de 10 informantes-chave, que eram trabalhadores de 10 diferentes áreas do hospital, selecionadas para o estudo, segundo a classificação legal canadense de RSS. A análise dos dados fundamentou-se em Bardin (1972), percorrendo as três etapas básicas no trabalho de análise do conteúdo das entrevistas, tendo como elementos auxiliares os dados obtidos com a observação e check-list. Os resultados revelaram uma situação gerencial organizada nas áreas de risco mapeadas; porém, o comportamento dos geradores não correspondia integralmente às exigências e recomendações legais daquele país, o que corrobora nosso pressuposto inicial. Também permitiram a proposição de um protocolo a ser utilizado no Brasil, como estratégia auxiliar no gerenciamento de RSS. Este se constitui em um útil instrumento para os administradores e tomadores de decisão da área, apesar das diferenças sócio-econômicas e culturais em relação ao Canadá, podendo contribuir para o processo de avaliação e gerenciamento de risco ambiental, no sentido de colaborar para a construção de um ambiente ecologicamente adequado e de uma melhor qualidade de vida.

Palavras-Chave: Resíduos de Serviços de Saúde; Gerenciamento de Riscos; Gerenciamento de Resíduos; Saúde Ambiental. 


\begin{abstract}
TAKAYANAGUI, AMM. Environmental risk and waste management in a university hospital in Canada - a case study. 2004. 83 f. Tese (Livre Docência) - Escola de Enfermagem de Ribeirão Preto, Universidade de São Paulo, Ribeirão Preto, 2004.
\end{abstract}

The environmental impacts caused by solid urban waste represent one of the main questions for public administrators, due to their risks for health and the environment. Medical waste stands out in this context, due to the fact that, although representing about $2 \%$ of the total quantity of urban waste, this kind of waste offers risks due to the presence of biological, chemical and/or radioactive agents. As opposed to what happens in developed countries, in Brazil, medical waste is still not managed in accordance with the recommendations found in more developed situations with respect to handling, treatment and final destination. This research aimed to get to know and describe the management structure of the medical waste produced at McMaster University Medical Centre - MUMC - Canada, with a view to the implementation of new strategies in the Brazilian reality when making decisions in environmental risk evaluation and management processes. Our premise was based on the existing similarities between Canada and Brazil with respect to how medical waste is handled and discarded, in spite of the higher level of legal organization and technical-operational and political conditions in Canada. This descriptive and exploratory case study is based on semistructured interviews, systemized observation and a check-list. Research subjects were 10 key informants, working at 10 different hospital areas selected for the study, in accordance with the Canadian medical waste classification. Data analysis was based on Bardin (1972), covering the three basic steps in analyzing the contents of the interviews, supported by the data obtained through observations and the check-list. Results displayed an organized management situation in the mapped risk areas, although waste creators' behavior did not correspond totally to the Canadian legal demands and recommendations, which corroborates our initial premise. The obtained results also allowed us to propose a protocol, to be used in Brazil as an auxiliary strategy for managing medical waste. This is a useful tool for managers and decision makers in this area, in spite of socioeconomic and cultural differences in relation to Canada, with the possibility of contributing to the environmental risk evaluation and management process and of help in the construction of an adequate ecological environment and a better quality of life.

Keywords: Medical/Infectious Waste; Risk Management; Waste Management; Environmental Health. 


\section{RESUMEN}

TAKAYANAGUI, AMM. Riesgo ambiental y el gerenciamiento de residuos en los espacios de un servicio de salud en Canada - un estudio de caso. 2004. $83 \mathrm{f}$. Tese (Livre Docência) - Escola de Enfermagem de Ribeirão Preto, Universidade de São Paulo, Ribeirão Preto, 2004.

Los impactos ambientales causados por los residuos sólidos urbanos representan una de las principales cuestiones para los administradores públicos, por los riesgos a la salud y al ambiente. Entre esos residuos, se destacan aquellos generados en servicios de salud (RSS) los cuales, a pesar de representar cerca de $2 \%$ en relación al total de residuos urbanos, constituyen un riesgo por poseer agentes biológicos, químicos e/o radioactivos en parte de su volumen generado. Al contrario de lo que ocurre en países desarrollados, en Brasil, el gerenciamiento de los RSS todavía no está de acuerdo con las recomendaciones encontradas en otras realidades más desarrolladas, tanto en relación a su manuseo, como al tratamiento y a la destinación final. Esta investigación tuvo como objetivo conocer y describir la estructura del gerenciamiento de los residuos producidos en el McMaster University Medical Centre MUMC, en Canadá, teniendo como finalidad la implementación de nuevas estrategias metodológicas que pudiesen ser aplicadas para la realidad brasileña, en la tomada de decisión en procesos de evaluación y gerenciamiento del riesgo ambiental. Nuestro presupuesto estaba basado en la similitud de la situación de la manipulación y descarte de los RSS, por los generadores, en relación a la situación existente en Brasil, a pesar de mayor desarrollo de la organización legal, de las condiciones técnico-operacionales y políticas del Canadá. Esta es una pesquisa descriptiva y exploratoria, constituyéndose en un estudio de caso, basado en entrevistas semi-estructuradas, en observación sistematizada y en un chek-list. Los sujetos se constituyeron de 10 informantes-claves, trabajadores de 10 áreas diferentes del hospital seleccionadas para el estudio, segundo la clasificación legal canadiense de los RSS. El análisis de los datos se fundamentó en Bardin (1979), percorriendo tres etapas básicas en el análisis del contenido de las entrevistas, teniendo como elementos auxiliares los datos obtenidos con la observación y el chek-list. Los resultados revelaron una situación gerencial organizada en las áreas de riesgo mapeadas; sin embargo, la condición del comportamiento de los generadores todavía no correspondió totalmente a las exigencias y recomendaciones legales de aquel país, lo que corrobora nuestro presupuesto inicial. También, permitieron la propuesta de un protocolo para ser utilizado en el Brasil, como estrategia auxiliar en el gerenciamiento de RSS. Éste constituye un útil instrumento para los administradores y tomadores de decisión del área, a pesar de las diferencias socio-económicas y culturales en relación al Canadá, pudiendo contribuir para el proceso de evaluación y gerenciamiento del riesgo ambiental, en el sentido de colaborar para la construcción de un ambiente ecologicamente adecuado y de una mejor calidad de vida.

Palabras claves: Residuos de Servicios de Salud, Gerenciamiento de Riesgos, Gerenciamiento de Residuos, Salud Ambiental. 


\section{INTRODUÇÃO}

Desde os primórdios da humanidade o homem vem criando uma situação de desequilíbrio crescente com o meio ambiente, resultante do desenvolvimento e do alcance de tecnologias cada vez mais sofisticadas. Ao mesmo tempo, ele também vem se organizando no sentido de entender melhor o que se passa nessa relação com o seu meio, buscando soluções alternativas para os problemas com os quais vai se deparando.

De acordo com Ross (1974, p.171), a Academia Nacional de Ciências dos Estados Unidos já ensaiava, em 1916, uma maior dimensão para o entendimento dos problemas oriundos da relação do homem com o meio ambiente, através do Relatório Sumário sobre Recursos Naturais, por ela elaborado, que afirmava que "as mudanças que o homem forjou no equilíbrio das grandes forças naturais e no novo micro-ambiente que ele criou, só são sentidas fracamente e não são compreendidas de todo".

Foi apenas a partir da metade do século XX que o homem começou a dar indicações da aquisição de um processo de maior compreensão sobre o problema. Em 1972, o Clube de Roma produziu relatórios de grande repercussão, sendo o mais conhecido "Os Limites do Crescimento", cujas conclusões indicavam que a humanidade tinha que conter o seu crescimento demográfico e econômico, modificando sua filosofia de vida e conseqüentemente seu comportamento, em função do caos a que estaria fadada se continuasse em desordenado crescimento (MEADOWS et al., 1973; COIMBRA, 1985; MASSAMBANI \& CAMPIGLIA, 1992).

Mas, foi na Suécia, em 1972, que ocorreu o primeiro grande evento em relação ao meio ambiente, a Conferência Internacional de Estocolmo, organizada pelas Nações Unidas, da qual participaram 113 nações, com elaboração de uma série de recomendações a fim de melhorar 
as relações entre o homem e o meio ambiente. A partir daí, o homem começou a demonstrar mais concretamente mudanças na percepção a respeito dos problemas ambientais.

Nessa Conferência foram debatidas, principalmente, questões a respeito do "dano causado ao planeta pelas atividades humanas, do modelo de desenvolvimento e do confronto de posições entre países desenvolvidos e em desenvolvimento" (IMPERATRIZ-FONSECA et al., 1992, p.111).

Este evidente confronto entre países industrializados e os não industrializados resultou na clara constatação de que a pobreza é uma das maiores causas da deterioração do meio ambiente (COIMBRA, 1985; ALVARENGA, 1992).

Em 1987, foi elaborado o relatório Our Common Future, conhecido como relatório Brundtland, pela Comissão Mundial sobre Meio Ambiente e Desenvolvimento, para o Programa das Nações Unidas para o Meio Ambiente - PNUMA, visando estabelecer uma "relação harmônica entre desenvolvimento econômico e a preservação ou conservação dos recursos naturais" (RATTNER et al., 1992, p.85).

Esta foi uma das principais vertentes da II Conferência das Nações Unidas sobre Meio Ambiente e Desenvolvimento - CNUMAD, também chamada de ECO - 92 ou Conferência Rio 92, realizada em junho de 1992, no Rio de Janeiro, Brasil.

NA ECO - 92 foi elaborado um Programa de Saneamento do Ambiente Mundial para o século XXI, baseado no conceito de desenvolvimento sustentado e traduzido pela AGENDA 21.

Naquela reunião também foram firmadas duas convenções gerais para proteção do clima e da biodiversidade, tendo como objetivo a proteção da extinção das espécies vivas do Planeta, além de duas declarações, uma delas de Princípios sobre Florestas e a Carta da Terra. 
Cinco anos mais tarde, em março de 1997, foi promovida a Conferência Rio + 5 visando avaliar o alcance dos objetivos traçados no evento anterior, tendo sido constatada a morosidade com que avanços e progressos vinham ocorrendo nessa direção.

Dentro desse contexto tem-se valorizado a interdependência entre a questão ambiental e a saúde humana. Atualmente, já não há mais dúvida de que ambientes com saneamento adequado, como: cuidado com os resíduos sólidos, com a emissão de poluentes gasosos, com a poluição das águas e dos alimentos, ao lado de melhores condições sociais e de comportamentos da sociedade ecologicamente adequados, entre outros, contribuem sobremaneira para um maior nível de saúde e uma melhor qualidade da vida urbana.

A saúde ambiental, enquanto área do conhecimento que estuda as questões que envolvem a saúde humana em função de problemas existentes no ambiente, começou a ganhar força no final deste século, embora fosse uma preocupação antiga, descrita por Hipócrates 400 anos a.C. (ORDÓÑEZ, 2000).

A questão da degradação ambiental e seu efeito adverso à saúde humana têm adquirido importância, não apenas para a sociedade, como também para a área acadêmica. Atualmente há um considerado avanço em alguns centros de pesquisa nessa área, o que tem contribuído para um melhor entendimento dos problemas relacionados à saúde ambiental (COLE et al., 1995; JAMES \& EYLES, 1999; GOEHL, 2000; EDULJEE, 2000; EYLES et al., 1999; LUGINAAH et al., 2000).

Alguns autores consideram que a pesquisa em saúde ambiental ainda não alcançou muita confiabilidade na área acadêmica devido à alta variabilidade de determinantes presentes em cada investigação (NEUTRA,1985; FRANK et al., 1988; ELWOOD, 1998; BAXTER et al., 1999 a). Segundo Frank et al.(1988), apesar do fato de que diferentes abordagens metodológicas venham sendo utilizadas nesse campo de conhecimento, a verdade é 
que quase nenhum dos efeitos à saúde humana, conhecidos como resultantes de uma exposição química, é totalmente específico para aquela exposição.

As incertezas e controvérsias em pesquisas de saúde ambiental estão quase sempre presentes nesses estudos e podem gerar controvérsias quanto à interpretação dos problemas pelo público, pelos administradores e também pelos cientistas, embora essas pesquisas estejam sendo realizadas através de métodos epidemiológicos (NEUTRA,1985; FRANK et al., 1988; COULTER \& NOSS, 1988; BROWN, 1992; ELLIOTT et al., 1993).

Adicionalmente, modelos biológicos e epidemiológicos, embora considerados como fundamentais para a ciência das políticas públicas, são ainda utilizados de uma maneira limitada, especialmente na esfera das legislações ambientais e nas questões relativas à informação e avaliação de risco ambiental devido a uma exposição (NEUS et al., 1999; CALDERON, 2000).

De acordo com Vena \& Weiner (1999), inovações deveriam ser trazidas para os métodos epidemiológicos no campo da saúde ambiental, iniciando por novos paradigmas acerca do conceito de determinantes de saúde, com a incorporação de novas idéias e o uso de uma abordagem multidisciplinar, de forma a se obter um melhor alcance das soluções para os problemas de saúde ambiental (DUVAL, 1998).

Para a comunidade científica, o corpo de conhecimento acadêmico deve ter fundamentações teórico-metodológicas concretas. Entretanto, na área de saúde ambiental há uma dificuldade em se produzir trabalhos científicos utilizando-se semelhantes modelos metodológicos, dado à complexidade da maioria dos estudos da área acadêmica, devido ao grande número de variáveis, freqüentemente presentes em pesquisas nesse campo de conhecimento, e pela diversidade e desdobramento de seus temas (EYLES, 1995; EYLES et al., 1999). 
A incorporação de abordagem qualitativa a dados quantitativos em pesquisas ambientais tem contribuído para um melhor entendimento dos aspectos relacionados à avaliação de risco ambiental e sua aplicabilidade em estudos dessa natureza; além disso, esta estratégia metodológica pode reduzir as incertezas sobre o fenômeno a ser investigado (SOFAER, 1998).

Entre as diferentes abordagens que têm alcançado importância nas pesquisas em saúde ambiental, Avaliação de Risco e Gerenciamento de Risco são instrumentos metodológicos que têm sido muito utilizados, assim como: os conceitos de Percepção de Risco e de Comunicação de Risco (HERTZMAN et al., 1989; KREWSKI \& BIRKWOOD, 1987; Toronto, 1991; COLE et al., 1995; EYLES et al.1999; EDULJEE, 2000). Isso tem contribuído para uma maior compreensão a respeito da relação existente entre risco ambiental e saúde (CANADA, 1993; ELLIOTT et al., 1997; BAXTER et al., 1999 b; ELLIOTT et al., 1999; JAMES \& EYLES, 1999; GOEHL, 2000; WAKEFIELD \& ELLIOTT, 2000).

De acordo com a Associação de Padronização Canadense (NATIONAL STANDARD OF CANADA,1997a , p.11), risco está presente em toda atividade humana e pode estar relacionado à saúde, segurança e economia ou afetar as condições ambientais, sendo definido como "a combinação da freqüência ou probabilidade de ocorrência com a consequiência de um evento específico de perigo". Em outra publicação, este mesmo organismo canadense acrescenta em sua definição de risco: "a chance de dano ou perda medida pela probabilidade e gravidade de um efeito adverso à saúde, propriedade, ambiente ou de outros valores" (NATIONAL..., 1997b, p.3).

Assim, Avaliação de Risco e Gerenciamento de Risco consistem em uma forma de abordagem mais sistemática que vem sendo desenvolvida há mais de duas décadas, principalmente na área de saúde ambiental. Estes conceitos têm sido importantes instrumentos nessa área, trazendo novas perspectivas para o estabelecimento de "prioridades e avaliação de efetividade nas opções de medidas de mitigação" (SEXTON, 1992, p.641). 
Primeiramente, "o risco possuído por um agente particular depende da natureza do perigo e da probabilidade de sua ocorrência" e o valor de seu efeito depende de fatores, tais como sua natureza, gravidade e grau de reversibilidade. Em relação à probabilidade ou chance da existência de algum efeito, "isto dependerá da potência do agente, da susceptibilidade do hospedeiro e do nível de exposição" (KREWSKI \& BIRKWOOD, 1987, p.53).

Vários modelos de Avaliação de Risco e de Gerenciamento de Risco têm sido propostos para a identificação do fator de risco em situações específicas, proporcionando importante informação científica para os administradores das políticas públicas, principalmente nos países do hemisfério norte (KREWSKI \& BIRKWOOD, 1987), significando que "as decisões baseadas no conceito de risco têm sido parte integrante do empenho das políticas públicas, no sentido de proteger a sociedade de efeitos perigosos à saúde por poluição ambiental" (SEXTON, 1992, p.635). Também Jauchem e Merrit (1991) afirmam que as políticas públicas já estão sendo regularmente influenciadas por dados epidemiológicos.

Entre esses métodos há algumas variações referentes aos passos a serem seguidos na sua operacionalização, em relação a informações sobre o fenômeno a ser analisado. O Comitê Científico sobre Problemas Ambientais dos Estados Unidos - SCOPE (KATES, 1978) formulou um dos primeiros modelos do processo de Avaliação de Risco utilizados, que consiste em três passos: a) identificação do risco, b) estimativa do risco e c) avaliação do risco. O estágio seguinte consiste da tomada de decisão de acordo com o resultado da Avaliação do Risco. Esta fase é denominada Gerenciamento de Risco (KREWSKI \& BIRKWOOD, 1987).

De acordo com esses autores, os demais modelos apresentam uma variação do modelo proposto pelo Conselho Nacional de Pesquisa dos Estados Unidos - NRC, também adotado pela Agência de Proteção Ambiental daquele país (Environmental Protection Agency EPA), desde a década de 80, que considera Avaliação de Risco como "os efeitos à saúde por exposição de indivíduos ou populações a substâncias ou situações perigosas" e Gerenciamento 
de Risco, como o processo de opções regulares de Avaliação de Risco (KREWSKI \& BIRKWOOD, 1987, p.54).

Para Cole (1995), Avaliação de Risco significa uma estimativa qualitativa ou quantitativa da probabilidade da ocorrência de efeitos adversos resultantes de exposição específica a perigos à saúde ou então pela ausência de influências benéficas, tendo geralmente, como componentes, a identificação do perigo e a avaliação da exposição e de sua dose, analisadas de forma integrada.

A Associação de Padronização Canadense (NATIONAL..., 1997 a, p.7) segue o esquema de Avaliação de Risco que incorpora diferentes passos desde a "identificação inicial e análise do risco até a avaliação de sua tolerabilidade e identificação das opções para redução do risco em potencial, através da seleção, implementação e monitoramento de medidas de redução e de controle apropriado".

Esses passos de Avaliação de Risco são compreendidos por análise do risco (definição, identificação e estimativa do risco) e avaliação do risco (análise das opções e decisões relativas à tolerabilidade ao risco existente). Já, o processo de Gerenciamento de Risco abrange, além do processo de Análise de Risco, um estágio denominado redução ou controle de risco (tomada de decisão, implementação e monitoramento), tendo como objetivo "a prevenção ou redução de dano ou perda de vida, doença, dano à propriedade ou dano ambiental" (NATIONAL..., 1991, p.13).

Para Eyles (1994), em se tratando de risco ambiental, os aspectos quantitativos podem ser construídos matematicamente, sendo alguns hipotéticos, trazendo o significado de transferência de impactos para indivíduos, comunidades ou países, em função da chance que esses riscos podem ter para eles. Segundo este autor, "risco implica, principalmente, em efeitos adversos", sendo resultante de processos da modernização, atravessando as fronteiras de ordem social e quebrando as barreiras existentes entre países, grupos ou indivíduos”. O mesmo ocorre 
com os riscos ambientais e ecológicos que transcendam as fronteiras legais construídas pelos homens (EYLES, 1994, p.13).

Agravando a escassez de informação sobre exposição e seus efeitos à saúde humana, há, também uma escassez de pesquisas metodologicamente bem delineadas em situações de exposição ambiental, assim como uma ausência de adoção de biomarcadores e de pesquisas sobre percepção de risco e seus determinantes sociais (SCHULTE, 1995; VRIJHEID, 2000).

No Brasil, essa área de conhecimento é relativamente nova, pois só começou a tomar vulto praticamente na última década, com limitada aplicação prática de pesquisas sobre riscos ambientais e tecnológicos no campo da saúde ocupacional (PORTO \& FREITAS, 1997) e sobre diferentes determinantes de risco em saúde ambiental (TAKAYANAGUI, 1993; MOREL, 1992; ROSS \& FERREIRA-PINTO, 2000; LIEBER\&ROMANO-LIEBER, 2003), mas ainda assim sem maiores avanços deste tema, enquanto estratégia metodológica de Avaliação e de Gerenciamento de Risco em saúde ambiental.

\subsection{Residuos de Serviços de Saúde - RSS}

Todo e qualquer serviço que desenvolva algum tipo de atividade relativa à saúde humana e animal produz resíduos de serviços de saúde que, embora gerados em um pequeno volume (entre 10 e $20 \%$ em relação ao volume total de resíduos urbanos), representam um problema sanitário e ambiental, pela possibilidade de serem constituídos por agentes de origem biológica, química ou radioativa (WHO, 1985; U.S., 1988; OSHA, 1991;

CCME, 1992; ONTARIO, 1994; CANADA, 1997 a,b; THOMAS, 1997; ALLERMANN \& POULSEN, 2000; SILVA, 2000; TORONTO, 2000).

Atualmente, dentre os problemas ambientais, os resíduos sólidos, e, dentre estes, os resíduos de serviços de saúde, representam um importante tema estudado em 
pesquisas da área de saúde ambiental, devido a danos e consequiências, tanto para a saúde humana quanto para o ambiente, pela possibilidade de risco de exposição a produtos perigosos, que variam de acordo com diferentes fontes geradoras.

Além disso, o manuseio, tratamento e métodos de disposição final dos resíduos de serviços de saúde, tais como incineração e aterro sanitário, freqüentemente utilizados, podem gerar também outros tipos de ameaça à saúde humana e ao ambiente (WHO,1985; HERSHKOWITZ, 1990; BROWN,1990; MOREL,1992; MORITZ, 1995; BLENKHARN, 1995; ELLIOTT et al., 1997; ELLIOTT, 1998; HCWH, 2000).

Os resíduos de serviços de saúde têm diferentes classificações e definições, que variam de acordo com os regulamentos específicos de cada país e mesmo em cada estado ou governo provincial, como no caso do Canadá, onde há diferentes regulamentos específicos no nível federal e regional, resultando em significativas diferenças nas regras para manuseio desses resíduos (CCME,1992).

Os resíduos de serviços de saúde podem ser encontrados na literatura com diferentes terminologias, como: resíduo patológico, lixo hospitalar, resíduo infectante, resíduo biomédico, ou resíduo perigoso, dentre outras. Esta última denominação inclui, geralmente, os resíduos de origem biológica, química e radioativa, como no Brasil, onde os RSS são considerados do tipo Classe I - Perigosos, de acordo com a NBR-10.004 da Associação Brasileira de Normas Técnicas (ABNT, 1987).

Há uma tendência acadêmica em se considerar os RSS como uma importante questão a ser gerenciada nas instituições de saúde, principalmente pelo risco de transmissão de certos patógenos encontrados no sangue e derivados, como o vírus da hepatite B (HBV), da hepatite C (HCV) e vírus da imunodeficiência humana (HIV), tanto de pacientes para trabalhadores da saúde ou o inverso (WHO, 1985, McKELVEY,1991; MALAVAUD \& 
MARTY, 1997; DALEY, 1999; BOCKHOLD, 2000; CANADA, 2000; WESTER \& MAIBACH, 2000).

Recentemente foi relatado na Inglaterra um caso de transmissão do Mycobacterium tuberculosis para um trabalhador de serviço de embalsamento de cadáver, adquirido durante um procedimento de rotina com um paciente que havia morrido com AIDS e tuberculose, mostrando a existência de risco à exposição também nessa situação (STERLING et al., 2000, p.246), e também a investigação que confirmou a transmissão desse mesmo agente patogênico para três trabalhadores de um serviço de tratamento de RSS, nos EUA (JOHNSON et al., 2000).

O Centro de Laboratórios para Controle de Doenças do Ministério da Saúde do Canadá elaborou um consenso sobre trabalhadores infectados em serviços de saúde, reconhecendo a importância de se prevenir a transmissão de patógenos presentes no sangue e iniciando um processo de avaliação de risco na transmissão de doenças, nesses serviços (CANADA, 1998).

Os RSS também têm sido considerados como um risco de exposição para qualquer pessoa que entre em contato com eles durante o seu manuseio, segregação, acondicionamento, coleta, transporte e armazenamento internos nos serviços de saúde. O risco também pode estar presente no processo de coleta e transporte externos, tratamento e disposição final, realizados fora dos serviços de saúde. Assim, os RSS representam um problema de ordem física, sócio-econômica e sanitária, além de ambiental, devido ao risco de exposição existente em todas as fases de seu processamento.

De acordo com os padrões para manuseio, tratamento e disposição de resíduos do Conselho Canadense de Ministros do Meio Ambiente (CCME, 1992), os resíduos de serviços de saúde, denominados resíduos biomédicos (biomedical wastes) naquele país, são definidos como os resíduos gerados em: a) serviços de assistência à saúde humana e animal, 
b) estabelecimentos de ensino e pesquisa médica ou veterinária, c) estabelecimentos de ensino em saúde, d) laboratórios de pesquisa e análises clínicas, e) serviços envolvidos na produção ou análise de vacinas.

Esta definição não se aplica aos resíduos que tenham sido descontaminados ou tratados antes de seu descarte, nem inclui resíduos de criação de animais ou gerados na produção de alimentos, manutenção geral de prédios e atividades administrativas daqueles serviços em que se aplica esta definição.

A região de Ontário segue a Regulamentação no.347 de 1990 e o Guia de Orientação C-4 de 1994, elaborados pelo Ministério do Meio Ambiente de Ontário (ONTARIO, 1994), que adota a mesma definição federal para os RSS, que se limitam aos seguintes tipos de resíduos:

a) resíduo anatômico humano;

b) resíduo de animais;

c) resíduo não anatômico;

d) culturas, lâminas ou espécimes humanas e de animais;

e) sangue líquido humano ou seus derivados;

f) perfurocortantes, agulhas, vidros quebrados e outros que sejam capazes de causar ferimentos, desde que supostamente infectados com um ou mais agentes listados na relação 5A do Guia de Orientação C-4 (ONTARIO, 1994).

A filosofia do governo da província de Ontário é voltada para a redução e reciclagem de resíduos, desde que certificados por escrito, pelo estabelecimento gerador, de que o resíduo não contenha nenhum dos tipos de agentes listados na Relação 5 A do Guia C-4 (com risco de exposição patogênica ), nem que tenha tido contato com animal ou ser humano tratado ou sob suspeita de estar infectado com um ou mais dos referidos agentes patogênicos. 
No Brasil, até o início da década de 90, não havia legislação ou regulamento tão amplo e específico para os RSS como no Canadá, e, somente nesta última década, foram editados regulamentos pelo Conselho Nacional do Meio Ambiente - Resoluções do Conselho Nacional do Meio Ambiente - CONAMA no. 5/93 e 283/01 (BRASIL, 1993 e 2001) e pela Secretaria de Estado da Saúde do Estado de São Paulo, em conjunto com outros órgãos públicos - Resolução Conjunta SS/SMA/SJDC no.1/98 (SÃO PAULO, 1998).

Estas Resoluções trouxeram melhores diretrizes para o gerenciamento dos RSS, que são classificados por ambas legislações, em quatro grupos, de acordo com os agentes presentes em sua composição, ou seja: Grupo A - biológicos, Grupo B - químicos, Grupo C radioativos e Grupo D - Resíduos comuns, semelhantes àqueles produzidos nos domicílios.

Entretanto, desde abril de 2003, o próprio sistema público político acabou gerando uma controvérsia entre os geradores, os serviços públicos fiscalizadores e a comunidade científica dessa área, com a edição de uma nova Resolução RCD-33/03, pela Agência Nacional de Vigilância Sanitária - ANVISA, trazendo alteração das exigências legais que se baseiam em um conceito de risco de menor abrangência, em relação à periculosidade dos RSS (RRASIL, 2003).

Apesar de alguns avanços trazidos por esta nova legislação, principalmente relacionados a uma melhoria do sistema gerencial dos RSS, algumas normas nela contidas seguem uma concepção diferente do que se encontra na grande maioria dos estudos sobre os riscos e impactos à saúde e ambiente, causados pela geração, manuseio e descarte dos resíduos produzidos em instituições de saúde, sejam na forma sólida, líquida ou gasosa, como evidenciado nas pesquisas de Driver \& Parcker (2001), Stalikas et al. (2001), Silva et al. (2002) e Neely et al. (2003).

Essa nova legislação classifica os resíduos em 5 grupos, incluindo vários tipos de resíduos considerados como perigosos nas legislações anteriores, no grupo dos resíduos comuns, 
não perigosos, diferentemente da legislação até então vigente (BRASIL, 2003). Essa controvérsia pode significar um movimento retrógrado para o sistema de gerenciamento dos RSS, que ainda não se encontra institucionalizado nos serviços de saúde brasileiros.

A situação, portanto, revela que há, ainda, a necessidade de novas diretrizes mais amplas e específicas no Brasil, não apenas para o manuseio interno dos RSS, mas principalmente para o sistema de manuseio externo, tratamento e disposição final desses resíduos, haja vista que grandes volumes de RSS são ainda dispostos em lixão a céu aberto sem tratamento, neste país que despeja cerca de $76 \%$ dos resíduos sólidos no solo ou em corpos d’água, incinera cerca de 0,1\% do lixo e tem $23 \%$ deles em aterros sanitários (IBGE, 2000).

Por outro lado, apesar de que legislações específicas e regulamentos possam trazer importante contribuição para o gerenciamento dos RSS, isto não é suficiente para assegurar um eficiente sistema gerencial, se não houver um programa de educação continuada visando manter todos os envolvidos no processo bem informados e conscientizados sobre a importância de seu adequado manuseio.

O gerenciamento de RSS requer um sistema organizado para apoiar todos os passos do processamento interno e externo à instituição geradora, iniciando com adequada segregação e acondicionamento, até as fases de coleta, transporte, tratamento e disposição final. Ambos os sistemas, interno e externo, de gerenciamento desse tipo de resíduo devem manter um programa de educação continuada aos seus trabalhadores, de acordo com as legislações e regulamentos específicos (THOMAZ, 1997).

Em um estudo sobre o gerenciamento de RSS no município de Ribeirão Preto, São Paulo, Brasil, em 1993, constatamos que apenas um terço (uma entre três toneladas/dia) desse tipo de resíduo produzido era destinado à incineração pelo sistema municipal, entrando os demais dois terços para o sistema de coleta de lixo domiciliar ou comum, destinados ao aterro sanitário do município sem nenhum tratamento prévio Takayanagui (1993). 
Também observamos que um elevado percentual (70,3\%) de RSS não estava sendo manuseado, em todas as suas fases de processamento, de acordo com as exigências legais e recomendações específicas do país, nos treze hospitais estudados do município de Ribeirão Preto.

Adicionalmente, há no Brasil poucas iniciativas dirigidas a esse tipo de problema (TAKAYANAGUI,1993; MOREL, 1995; TAKAYANAGUI et al., 1999; LEMOS et al., 1999), o que poderia contribuir para uma maior abrangência da implantação de sistemas mais seguros e organizados de gerenciamento dos RSS no país.

Considerando que os RSS podem ser um agente em potencial de risco à saúde humana e ao ambiente, o processo de Avaliação e de Gerenciamento de Risco em situações de sua produção pode representar uma nova abordagem metodológica, visando à implementação de ações voltadas para propiciar maior segurança em ambientes de trabalho na área da saúde. Além disso, essa estratégia ainda não tem sido utilizada no gerenciamento dos RSS, e tampouco esses resíduos têm sido rotineiramente inseridos no planejamento e gestão dos serviços de saúde.

Assim, interessa-nos ter como objeto de estudo o gerenciamento de resíduos de serviços de saúde junto ao McMaster University Medical Centre - MUMC, no Canadá, como um conhecimento para a tomada de decisões nessa área, em processos de: avaliação e gerenciamento de risco ambiental, e também com vistas ao desenvolvimento de um novo instrumento para o gerenciamento de resíduos de serviços de saúde no Brasil, por meio de um protocolo fundamentado na situação gerencial dos RSS naquela instituição de saúde canadense, podendo representar um meio facilitador de avaliação da situação dos RSS para os administradores, promovendo novas práticas de seu gerenciamento, a partir dos conceitos de Avaliação e Gerenciamento de Risco. 


\subsection{Pressuposto}

Embora conhecendo o avanço das legislações canadenses sobre o manuseio e descarte dos RSS, o que representa um importante passo no processo de gerenciamento de risco relacionado ao controle desse tipo de resíduo em instituições hospitalares, e, ainda, baseados em nossa vivência com essa mesma situação gerencial no Brasil, nosso pressuposto é de que há uma semelhança nesse contexto ambiental hospitalar no Canadá, não tão acentuada nos aspectos cognitivos, mas principalmente em relação aos geradores de resíduos, nos serviços de saúde. 


\section{OBJETIVOS}

\subsection{Geral}

Conhecer e descrever o processo tecnológico e a estrutura de gerenciamento dos RSS produzidos no McMaster University Medical Centre - MUMC, Canadá, visando a implementação de novas estratégias metodológicas para inserção da questão referente a esse tipo de resíduo no gerenciamento dos serviços de saúde.

\subsection{Especificos}

- Identificar as fontes geradoras de RSS no MUMC;

- Identificar os diferentes tipos de RSS produzidos no MUMC;

- Identificar os passos do gerenciamento de RSS, desde a segregação, acondicionamento, coleta, transporte, armazenamento, tratamento até a disposição final, ambos interno e externo ao MUMC; 


\section{DESENHO METODOLÓGICO}

Esta investigação é de cunho qualitativo, descritiva e exploratóra, baseada no diagnóstico da situação do gerenciamento dos RSS produzidos em um hospital universitário situado em Hamilton, cidade da região de Ontário, Canadá.

Sua metodologia fundamenta-se em conceitos trazidos por Gomes (1994), (Triviños, 1995), Minayo (1996), Sofaer (1999) e nas publicações da Agency for Health Care Policy and Research-AHCPR. Neste referencial é reforçada a importância da compreensão e explicação da dinâmica das relações sociais que, por sua vez, são depositárias de crenças, valores, atitudes e hábitos, destacando a vivência e a cotidianidade, assim como a compreensão das estruturas e instituições, resultantes da ação humana objetiva.

Como um estudo exploratório, permite o alcance de maior experiência a respeito do problema desta investigação, que se constitui em um estudo de caso, uma vez que se busca um conhecimento mais profundo a respeito de uma unidade específica, representada, neste estudo, pela condição de gerenciamento dos RSS numa instituição canadense.

De acordo com Minayo (1996, p.21-2), a pesquisa qualitativa se preocupa com um nível de realidade que não pode ser quantificada, correspondendo a um espaço mais profundo das relações, dos processos e dos fenômenos que não podem ser reduzidos à operacionalização de variáveis".

Assim, elegemos como técnica de coleta de dados a entrevista semiestruturada, na qual, segundo essa mesma autora, a relação entrevistado/entrevistador deve ser 
a mais próxima possível, devendo-se almejar uma verdadeira interação ou o alcance da subjetividade.

Outro instrumento utilizado foi a observação, que se configura de diferentes modos, dependendo da inserção e do papel do investigador no campo. Ainda para Minayo (1996), a observação é considerada parte essencial do trabalho de campo da pesquisa qualitativa; com ela seguem junto os movimentos, os discursos e as ações dos sujeitos e suas relações recíprocas.

Neste estudo utilizamos a observação sistematizada e o check-list para obtenção do maior número possível de informações desejadas. De acordo com Yin (1999), esse é um procedimento de pesquisa qualitativa que envolve questões de adequacidade, conveniência, verificação de dados com informantes secundários e triangulação de dados, à semelhança da forma como se deu nossa coleta de dados.

\subsection{Local da Pesquisa}

O McMaster University Medical Centre - MUMC é um hospital-escola pertencente a McMaster University, centro de ensino e pesquisa de alto nível em saúde e meio ambiente. Guarda estreitas semelhanças com o Hospital das Clínicas da Faculdade de Medicina de Ribeirão Preto-USP, nos aspectos operacionais relativos ao gerenciamento dos RSS, local que tem servido de campo para a maioria das pesquisas que vimos desenvolvendo.

Um outro motivo da escolha do MUMC foi devido à existência de um programa de intercâmbio entre ambas as instituições de ensino universitário. Adicionalmente, há uma similaridade entre o município de Hamilton, no Canadá, com uma população de cerca de 350 mil habitantes, e o município de Ribeirão Preto, no Brasil, cuja população é de aproximadamente 500 mil habitantes. 
O McMaster University Medical Centre - MUMC é parte integrante da Hamilton Health Science Corporation - HHSC, que é uma empresa hospitalar privada, composta por 4 hospitais localizados na cidade de Hamilton, região de Ontário, no Canadá. Exceto o Chedoke Hospital, cada um desses hospitais oferece assistência hospitalar e ambulatorial integral a pacientes agudos. Entretanto, eles possuem uma diferente vocação para especializações, como mostrado abaixo, embora o atendimento não seja limitado a essas áreas específicas (HAMILTON HEALTH SCIENCE CORPORATION, 2000):

- Chedoke Hospital - especializado em Assistência Crônica e Reabilitação;

- Hamilton General Hospital - especializado em Trauma e Assistência MédicoCirúrgica;

- Henderson General Hospital - especializado em Oncologia;

- $\quad$ MUMC - especializado em Assistência à Saúde da Mulher e da Criança.

Em relação ao MUMC, o mesmo é localizado junto a McMaster University, na zona oeste da cidade, oferecendo serviços terciários aos residentes do município de Hamilton e da área centro-oeste de Ontário, juntamente com os demais hospitais da HHSC, que são responsáveis por aproximadamente 67\% dos leitos hospitalares (1.163 leitos) e $70 \%$ dos atendimentos ambulatoriais da região de Hamilton-Wentworth.

No mesmo local onde funciona o hospital, há também uma área destinada à pesquisa, sob a responsabilidade administrativa da McMaster University, havendo uma estreita relação com a Faculdade de Ciências da Saúde (Faculty of Health Sciences), propiciando campo de ensino e pesquisa para os cursos de Medicina, Enfermagem, Obstetrícia, Fisioterapia, Terapia Ocupacional e Cinesiologia.

Os resíduos produzidos em cada uma dessas áreas, de pesquisa e assistência, são gerenciados separadamente. O gerenciamento dos resíduos gerados pela área hospitalar é de responsabilidade do setor de Manutenção e Limpeza (Housekeeping Office) e os 
resíduos gerados nas áreas de pesquisa são administrados pelo setor de Segurança Ambiental e da Saúde (Environmental \& Health Safety Office). O presente estudo refere-se apenas aos RSS produzidos na área hospitalar.

\subsection{População de Estudo}

\subsubsection{INFORMANTES - CHAVE DO MUMC}

A estratégia metodológica utilizada para a identificação da população participante foi a denominada "snowball", em que, a partir de um primeiro informante, consegue-se atingir todos os indivíduos de interesse para o estudo, por indicação dos próprios participantes da pesquisa (DUNN, 1999). Assim, o primeiro passo desta investigação foi contactar a gerente do serviço de manutenção do MUMC, responsável pelos gerenciamento geral dos RSS, visando conhecer o sistema de gerenciamento de todos os tipos de resíduos produzidos no hospital e arrolar os sujeitos para as entrevistas.

Após este primeiro contato, foram realizadas visitas técnicas para as relevantes áreas de produção de RSS no hospital, de acordo com a classificação canadense para esse tipo de resíduo (CCME, 1992), a fim de alcançar maior visibilidade do sistema de seu gerenciamento nesses locais. Pelas visitas, selecionamos as áreas incluídas nesta investigação, na medida em que fomos recebendo indicações de novos contatos nas demais áreas subseqüntes, com os quais foram sendo agendadas entrevistas.

Alguns desses indivíduos, selecionados para participarem desta investigação, foram recomendados pelos gerentes ou trabalhadores de cada área. Devido à similaridade dos tipos de resíduos gerados, algumas dessas áreas foram agrupadas para as entrevistas, tais como: laboratórios e enfermarias. As áreas de alimentação foram excluídas da amostra, pois geram apenas resíduos do tipo comum, exceto a "cafeteria", onde são servidas refeições diversas para todo o pessoal de ensino e serviço, assim como pacientes e familiares ou pessoas da comunidade. 
Também foram contactados três gerentes de outros serviços de apoio do hospital, como serviço de apoio à pesquisa e assistência, departamento de controle de infecção hospitalar e departamento de segurança ambiental e saúde, para informações adicionais sobre o sistema de gerenciamento dos RSS. Estes três entrevistados não foram incluídos na população do estudo por não fazerem parte das áreas selecionadas.

\subsubsection{INFORMANTES - CHAVE EXTERNOS AO MUMC}

Foram contactadas outras categorias de profissionais externos ao MUMC, pertencentes a diferentes setores públicos e privados, responsáveis pela coleta, transporte, tratamento e disposição final de RSS, visando conhecer o sistema de gerenciamento externo de RSS. Para isso, foram realizadas visitas técnicas a usinas de tratamento de RSS, que utilizam autoclave, a estações de transbordo de resíduos sólidos comuns e de serviços de saúde, a usinas de incineração, compostagem e reciclagem de resíduos sólidos, à usina de tratamento e reciclagem de resíduos perigosos (químicos, tintas e pesticidas) e ao aterro sanitário municipal.

Esses entrevistados também não foram incluídos na população do estudo por não fazerem parte das áreas selecionadas, tendo servido para as informações adicionais para um melhor entendimento de todo o sistema de gerenciamento dos RSS produzidos no MUMC.

No total foram formalmente contactadas 21 pessoas considerando as entrevistas e visitas aos locais internos e externos ao MUMC, tendo sido selecionados 10 sujeitos para a população desse estudo, de acordo com os objetivos da investigação, focalizando os principais pontos de geração de RSS.

As informações foram obtidas através da observação do pesquisador e de entrevistas com trabalhadores que ocupam alguma função ou posição de liderança em cada 
área, tais como: direção ou membro da equipe de serviço nas áreas selecionadas, de modo que as respostas foram emitidas de acordo com a percepção desses indivíduos. A amostra populacional foi composta por 4 enfermeiras, 3 técnicos especializados, 2 gerentes e 1 farmacêutica. Apenas um dentre os 10 entrevistados era do sexo masculino.

Todos os participantes concordaram, previamente, em participar da investigação, por meio de um termo de consentimento livre e esclarecido, elaborado nos padrões canadenses (Anexo A).

As entrevistas foram realizadas com as lideranças responsáveis pelo gerenciamento dos RSS, antes da observação sistematizada da área, utilizando-se um formulário com perguntas semi-estruturadas sobre o gerenciamento dos RSS em cada área selecionada, e indagando-se sobre os diferentes tipos de RSS gerados, o acondicionamento e tratamento dos resíduos relatados pelos informantes, bem como sobre os problemas relacionados aos RSS (Apêndice A). Com o objetivo de identificar os entrevistados, foram numerados os formulários de 1 a 10, optando-se pela sigla IH (Inside Hospital Informant), que significava o informante-chave participante da investigação.

Para a observação sistematizada foi utilizado um roteiro previamente elaborado, abrangendo as diferentes fases do gerenciamento dos RSS na instituição hospitalar e auxiliando no mapeamento dos principais pontos de sua produção, bem como na listagem dos diferentes tipos de resíduos gerados, delineando todo o fluxo desses resíduos no hospital. Esse instrumento incluia, também, dados sobre o sistema externo de tratamento e disposição final dos RSS (Apêndice B).

Esses roteiros foram fundamentados em instrumento de avaliação da situação dos RSS utilizado em estudo semelhante realizado no Brasil, por Takayanagui (1993), em hospitais do município de Ribeirão Preto, estado de São Paulo. 
Após o processo das entrevistas e observação das áreas, com base nas respostas obtidas e nas orientações legais sobre o tema, foi realizado um check-list que constou de uma re-visita aos informantes, utilizando-se uma listagem com todos os tipos de resíduos gerados referidos, levantados durante as fases de observação e entrevista. (Apêndice C).

Esse check-list contou também com uma brochura com fotos dos diferentes tipos de acondicionamento de todos os RSS existentes no hospital, para auxiliar na sua identificação e lembrança (Anexo B); esses instrumentos foram apresentados aos mesmos indivíduos inicialmente entrevistados, aos quais foi solicitado que apontassem os resíduos gerados em cada área, em ordem decrescente pelo volume diário de produção, visando facilitar a identificação dos diferentes tipos de resíduos gerados e a confirmação dos itens nele contidos.

\subsection{Análise dos Dados}

Com o material empírico obtido nas entrevistas, na observação sistematizada e no check-list, procedemos a sua análise, fundamentados na proposta de Bardin (1979), que assinala três etapas básicas no trabalho de análise de conteúdo: pré-análise, descrição analítica e interpretação referencial (TRIVIÑOS, 1995).

Após leitura exaustiva das entrevistas e dos registros da observação sistematizada, procedemos à análise do material obtido, categorizando-os em tabela e figuras, de acordo com os temas-chave relacionados à estrutura do gerenciamento dos RSS e de acordo com as legislações e classificação desse tipo de resíduo no Canadá e região de Ontário (CCME, 1992; ONTARIO, 1994). Os diferentes tipos de resíduos referidos pelos entrevistados foram distribuídos nos pontos de geração selecionados, constituindo os dados para o mapeamento de risco para produção de resíduos nas áreas selecionadas. 


\section{RESULTADOS E DISCUSSÃO}

Após percorrermos as três etapas para a coleta de dados, e procedermos à análise do material, foi possível elaborar um mapa de risco para o local do estudo, delineando as principais fontes geradoras de RSS, assim como os diferentes tipos de resíduos gerados e o seu processamento até a destinação final, que descrevemos a seguir:

\subsection{Principais pontos de Geração de RSS}

Pela observação de diferentes áreas do hospital e baseados nas falas dos entrevistados, pudemos identificar vários pontos de geração de resíduos, de interesse para o gerenciamento dos RSS produzidos no MUMC. Consideramos que essas informações são especialmente importantes para os administradores e tomadores de decisão, como uma contribuição para o alcance de um ambiente de trabalho saudável e seguro em relação ao risco de exposição a agentes biológicos, químicos e radioativos, que podem estar presente nos RSS.

Inicialmente recebemos a indicação da gerente do setor de Manutenção e Limpeza para a inclusão de 5 áreas nesta investigação: Centro Cirúrgico, Laboratório Central, Salas de Parto, Farmácia e Laboratório de Patologia.

Durante o período de visitas de reconhecimento dos diversos setores do MUMC, nós incluímos mais 8 áreas, a saber: Enfermarias de Gastroenterologia e de Cirurgia, Emergência, Laboratório de Hematologia, Radiologia, Medicina Nuclear, Unidade de Assistência à Família e Áreas de Alimentação (restaurantes e lanchonetes), representadas pela 
cafeteria, sendo posteriormente agrupadas de acordo com a similaridade dos resíduos gerados, como as enfermarias e laboratórios, exceto o de Patologia, pela composição diferente de seus resíduos. Assim, esta investigação contou com uma amostra de 10 áreas do MUMC.

A maior razão de cada área ter sido selecionada e considerada como um dos principais pontos de geração de RSS do MUMC, está diretamente relacionada ao conceito de exposição de risco a agentes biológicos, químicos ou radioativos, que podem ser encontrados nos resíduos de serviços de saúde (SILVA et al.; STALIKAS et al. e DRIVER E PACKER, 2002). Um outro fator determinante dessa seleção está ligado às recomendações legais para manuseio dos RSS no Canadá e à literatura acadêmica, além de nossa experiência nessa área de conhecimento (WHO, 1985; CCME, 1992; TAKAYANAGUI, 1993; ONTARIO, 1994).

Obviamente existem outras áreas no MUMC que não foram incluídas neste estudo por não estarem produzindo resíduos classificados como de serviços de saúde. Assim, as áreas selecionadas foram as seguintes:

Centro Cirúrgico - Consideramos incluídos, nesta área, diferentes setores do hospital que desenvolvem atividades especiais, tais como cirurgia, unidades de terapia intensiva, unidade de cuidados especiais e similares.

Laboratório de Patologia - Nesta área são manuseados, principalmente, tecidos humanos e a área de exames necroscópicos foi incluída nesta categoria.

Laboratório Central - Esta categoria inclui todos os tipos de laboratório, exceto o de patologia, a saber: Hematologia, Microbiologia, Imunologia, Análises Clínicas e Genética, dentre outros.

Radiologia - Este setor não produz volume significante de RSS. Os tipos de resíduos mais importantes são os químicos usados na revelação de filmes de RX. No MUMC há um importante programa de reciclagem deste produto, com aproximadamente $98,5 \%$ de recuperação da prata. 
Medicina Nuclear - Este setor produz resíduo radioativo que significa um dos mais importantes tipos de resíduos gerados pela humanidade, pelo potencial dos danos advindos deste produto.

Emergência - Embora este setor tenha alguma similaridade com outras áreas do hospital, pelas características dos resíduos gerados, ela foi selecionada separadamente devido à importância das atividades desenvolvidas no setor e pelo volume de resíduos gerados.

Enfermarias - Nesta categoria foram incluídos todos os setores de internação, tais como: clínica médica, cardiologia, cirurgia geral, cardiovascular e torácica, endocrinologia, neurologia, otorrinolaringologia, hematologia e oncologia, ginecologia e obstetrícia, pediatria, urologia, psiquiatria e outras. Além disso, foram também considerados os setores de doenças tropicais e infecciosas, embora estes possam ser avaliados como um setor separado, pela necessidade de um manuseio mais restrito dos RSS.

Salas de Parto - Esta área foi considerada separadamente, embora mantenha alguma similaridade com o centro cirúrgico e enfermarias, no local de estudo.

Farmácia - Este é um outro setor que pode ser dividido em um maior número de categorias, como exemplo: dispensação de drogas ou outros setores farmacêuticos, dependendo da realidade de cada hospital.

Unidade de Assistência à Família - Foram incluídas nesta categoria todas as áreas de atendimento ambulatorial do hospital.

Consideramos as 10 diferentes áreas selecionadas neste estudo como os principais pontos de geração dos RSS no MUMC. Essas mesmas áreas também podem ser encontradas em situações semelhantes em outras instituições hospitalares, dependendo das atividades específicas do atendimento prestado à saúde, podendo sofrer algumas modificações do ponto de vista operacional. 
Durante a identificação do responsável pelos resíduos em cada área selecionada, foi observada uma certa dificuldade entre os trabalhadores para a identificação de lideranças que poderiam ser capazes de participar das entrevistas. Isto ficava claro quando era solicitada a participação de algum membro da equipe de trabalho da área, nas entrevistas desta pesquisa, conforme as falas de alguns trabalhadores, abaixo:

"Hum, isso não é comigo...” (IH 1)

"Isso é com o serviço de Manutenção e Limpeza" (IH 2)

"Eu não sei quem poderia responder sobre lixo aqui...” (IH 3)

Através destas falas podemos perceber que não era claro, para muitos dos trabalhadores, quem seria o encarregado pelo gerenciamento dos RSS; isso ocorreu em $60 \%$ das áreas, revelando a necessidade de se ter definido, em cada setor do hospital, um responsável direto por esta questão, apesar das legislações específicas no Canadá darem um enfoque para a importância de se manter um gerente com treinamento específico para os RSS nas instituições geradoras, o que ocorre igualmente no Brasil, porém sem a efetiva legitimidade, seja por falta de cobrança por parte dos órgãos fiscalizadores, seja por negligência ou desconhecimento dos administradores das instituições de saúde.

O contrário ocorreu em 40\% das áreas, como: Centro Cirúrgico, Laboratório de Patologia, Emergência e Farmácia, em que o respondente foi prontamente indicado pelos funcionários contactados, embora os entrevistados dessas áreas nem sempre tenham demonstrado ou verbalizado completo entendimento sobre a questão do gerenciamento dos RSS, principalmente quanto ao tratamento e destinação final dos resíduos. Alguns informantes disseram:

\footnotetext{
"é tão importante assim a questão dos resíduos?" (IH 4)

“interessante...eu nunca havia, antes, pensado nisso...” (IH 3)
}

Nenhum dos respondentes soube informar com precisão o volume dos resíduos gerados em sua área de trabalho. 
No hospital onde foi realizada esta pesquisa, o pessoal do Serviço de Manutenção e Limpeza é responsável pelo manuseio dos RSS somente após esses resíduos terem sido armazenados para coleta interna hospitalar, em local próximo à saída da área geradora, exceto nas enfermarias onde há um funcionário que trabalha fixo dentro destes setores.

A Figura 1 (abaixo) mostra o esquema das diferentes áreas identificadas como geradoras de RSS no MUMC e a relação com o serviço responsável pela coleta, transporte e armazenamento interno e apresentação dos resíduos à coleta externa. Pode-se observar que, independente do tipo de tratamento recebido, todos os resíduos gerados têm como principal forma de destinação final, em volume reduzido ou não, o solo, através de aterros sanitários, o que nem sempre ocorre do mesmo modo em algumas outras partes do Planeta, haja vista a situação no Brasil, em que cerca de $76 \%$ de seus resíduos são dispostos à céu aberto, sem qualquer tipo de tratamento prévio, ou ainda descartados em cursos d'água (IBGE, 2000), embora em torno de $70 \%$ dos domicílios urbanos do país possuam coleta de lixo domiciliar (LIXO MUNICIPAL, 2000). 


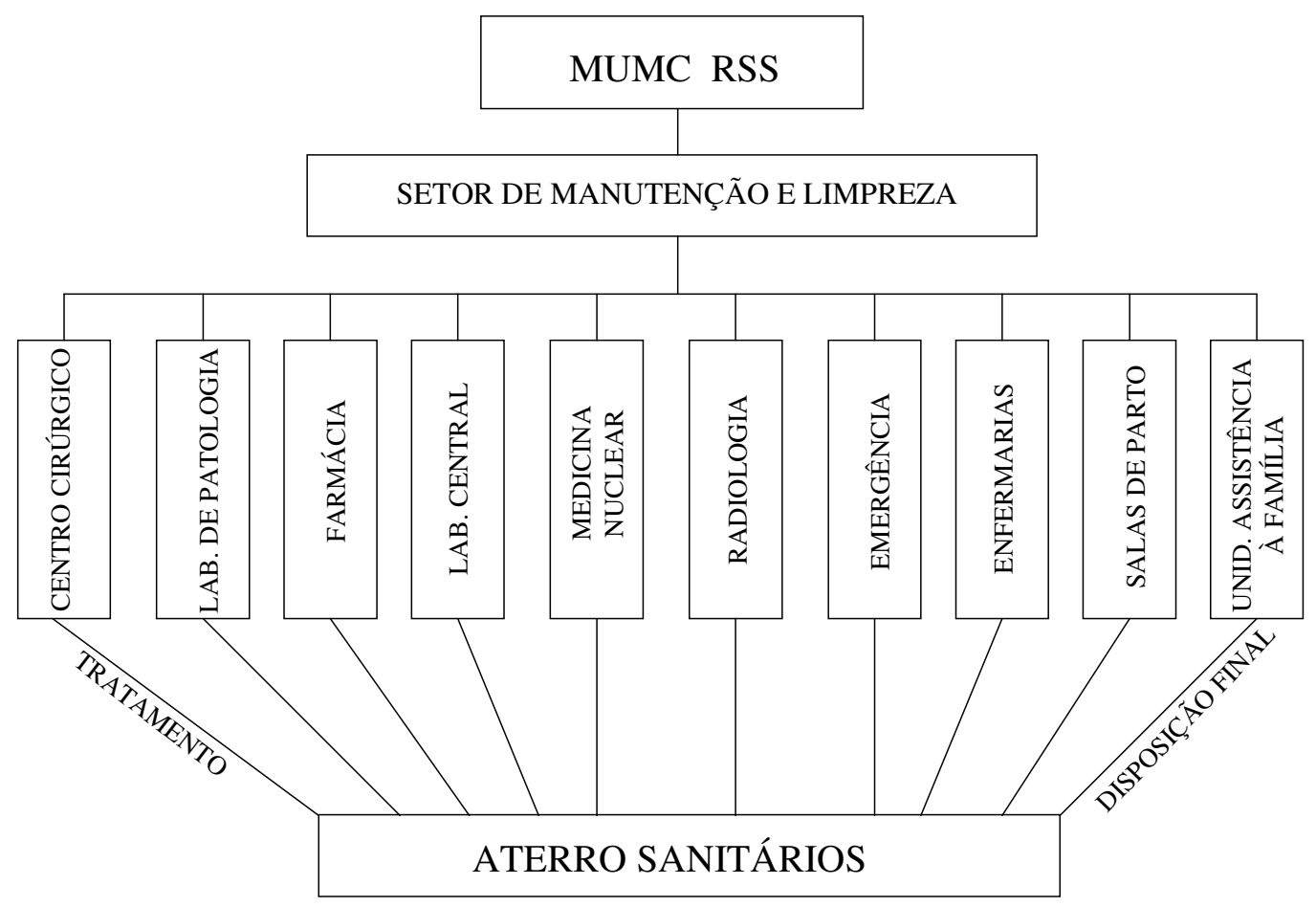

Figura 1: Produção e Disposição Final de Resíduos de Serviços de Saúde (RSS) gerados em diferentes Áreas do McMaster University Medical Centre - (MUMC) - Canadá 2000.

\subsection{Os Resíduos de Serviços de Saúde do MUMC}

Manter um ambiente de trabalho seguro e controlado nas instituições hospitalares é necessário e importante. Consideramos como primeiro passo para ações de gerenciamento dos RSS a identificação dos diferentes tipos de resíduos gerados e suas respectivas áreas geradoras, visando o planejamento do controle de risco através da estratégia de Avaliação de Risco e Gerenciamento de Risco; para isso, é necessário iniciar as atividades de gerenciamento dos RSS por um mapeamento das áreas onde são produzidos esses resíduos.

\subsubsection{Tipos de Resíduos Gerados no MUMC}

Através da análise das primeiras entrevistas e baseados na observação sistematizada, pudemos constatar que não haviam sido informados todos os tipos de resíduos 
gerados em cada área, de acordo com a classificação das legislações específicas e com a nomenclatura utilizada pela empresa responsável pela coleta, transporte, tratamento e disposição final dos RSS do MUMC. Algumas falas davam a impressão de que não se produzia qualquer tipo de material ou substância nociva ou de risco de exposição aos indivíduos ou ao ambiente:

"aqui você não encontra esse tipo de resíduo perigoso que você quer estudar (referindo-se aos resíduos de origem biológica, química ou radioativa), não posso ser muito útil para sua pesquisa” (IH 1) "nós não geramos nenhum tipo de resíduo aqui na clínica. Só igual ao que todo mundo produz...” (IH 10)

Após a aplicação do check-list, foi possível fazer uma conferência das informações obtidas, o que possibilitou a identificação dos seguintes tipos de resíduos:

- A) Resíduos Não-Anatômicos/Não Citotóxicos (Cortantes ou não cortantes)

- B) Resíduos Biológicos Anatômicos Perigosos (incluídos no Regulamento A da legislação canadense)

- C) Resíduos Biológicos Citotóxicos Perigosos (incluídos no Regulamento C da legislação canadense)

- D) Resíduos Farmacêuticos Perigosos (Classe 261 A, B, I, L)

- E) Narcóticos

- F) Resíduos Recicláveis

- G) Resíduos Comuns ou do tipo domiciliar

- H) Resíduos do tipo Confidencial

- I) Resíduos Perigosos (Tintas, Pesticidas e Químicos)

- J) Resíduos Radioativos 
Os resíduos correspondentes às letras $\mathrm{A}, \mathrm{B}$ e $\mathrm{C}$ são denominados pela nomenclatura da empresa coletora, como Biomédicos, ou de origem biológica, e os das letras D e E, Farmacêuticos; os demais seguem a nomenclatura das legislações canadenses e da província de Ontário(CCME, 1992; ONTARIO, 1994). O hospital também gera outros tipos de resíduos, tais como resíduos comuns ou do tipo domiciliares e móveis e equipamentos descartados pela instituição hospitalar, estes últimos não incluídos na listagem do check-list por não pertencerem ao grupo de interesse dos resíduos de serviços de saúde e terem uma freqüência de produção relativamente baixa, em relação aos demais.

A aplicação do check-list permitiu, também, a elaboração de um perfil dos principais tipos de resíduos gerados no MUMC. Do total dos 11 diferentes tipos de resíduos identificados, 6 destes são considerados como resíduos de serviços de saúde, de acordo com a legislação existente (CCME, 1992; ONTARIO, 1994). Estes resíduos são os 6 primeiros apresentados na Tabela 1, a seguir: 
Tabela 1 - Tipos de Resíduos Produzidos no McMaster University Medical Centre - MUMC, em ordem decrescente de volume gerado, e de acordo com as diferentes áreas geradoras - Canadá, 2000.

\begin{tabular}{|c|c|c|c|c|c|c|c|c|c|c|}
\hline Tipos de Resíduos & $\begin{array}{l}\text { Centro } \\
\text { Cirúrgico }\end{array}$ & $\begin{array}{l}\text { Laboratório } \\
\text { de Patologia }\end{array}$ & Farmácia & $\begin{array}{l}\text { Laboratório } \\
\text { Central }\end{array}$ & Enfermarias & Emergência & $\begin{array}{l}\text { Unidade de } \\
\text { Assistência à } \\
\text { Família }\end{array}$ & $\begin{array}{l}\text { Salas de } \\
\text { Parto }\end{array}$ & Radiologia & $\begin{array}{l}\text { Medicina } \\
\text { Nuclear }\end{array}$ \\
\hline $\begin{array}{l}\text { Não anatômicos/não } \\
\text { citotóxicos (cortantes ou } \\
\text { não cortantes) }\end{array}$ & 2 & 2 & 4 & 1 & 1 & 2 & 4 & 3 & 5 & 3 \\
\hline $\begin{array}{l}\text { Anatômicos / Biológicos } \\
\text { Perigosos * }\end{array}$ & 5 & 1 & - & - & 5 & 5 & 6 & 2 & - & - \\
\hline $\begin{array}{l}\text { Biológicos citotóxicos } \\
\text { Perigosos } * *\end{array}$ & - & - & 5 & - & - & - & - & - & - & - \\
\hline $\begin{array}{l}\text { Farmacêuticos não } \\
\text { Perigosos }\end{array}$ & - & - & 2 & - & 6 & - & 5 & - & - & - \\
\hline $\begin{array}{l}\text { Farmacêuticos Perigosos } \\
\text { (Classe 261A, B, I, L) }\end{array}$ & - & - & 3 & - & - & - & - & - & - & - \\
\hline Narcóticos & - & - & 7 & - & - & - & 7 & 6 & - & - \\
\hline Recicláveis & 3 & 4 & 6 & 3 & 4 & 4 & 1 & 5 & 2 & 4 \\
\hline Comuns & 1 & - & 1 & 4 & 2 & 1 & 2 & 1 & 3 & 1 \\
\hline Confidenciais & 4 & 3 & 8 & 2 & 3 & 3 & 3 & 4 & 4 & 5 \\
\hline $\begin{array}{l}\text { Perigosos (Tintas, } \\
\text { Pesticidas, Químicos) }\end{array}$ & - & 5 & - & - & - & - & - & - & 1 & - \\
\hline Radiativos & - & - & - & - & - & - & - & - & - & 2 \\
\hline
\end{tabular}


Os achados mostraram que os RSS têm sido gerados em todas as áreas selecionadas, revelando, também, outras importantes categorias de resíduo, que são: a dos químicos perigosos, tais como líquido fixador de $\mathrm{RX}$ e a dos radioativos, estando estes últimos sob legislação federal específica, tanto no Canadá como no Brasil.

Esta investigação não teve como objetivo central analisar o volume dos RSS produzidos, mas é possível ver pela Tabela 1 que o tipo de resíduo mais citado, dentre todos os tipos gerados no MUMC, de acordo com o volume de produção referido, foi o resíduo do tipo comum em $50 \%$ das entrevistas. Esse dado é encontrado na literatura de modo semelhante (TAKAYANAGUI, 1993).

Um dado adicional, obtido durante as entrevistas, revelou que alguns tipos de resíduos de origem biológica, tais como campos cirúrgicos sujos com sangue, alguns restos de material usado em curativos, lâminas e placas de análises patológicas, dentre outros, são descartados como resíduos do tipo comum e não infectante, tendo sido elevado o número de vezes em que esse tipo de resíduo foi apontado pelos entrevistados, com esse tipo de descarte.

"oh, esse material vai para o lixo, é descartado nos sacos de lixo comum!" (H 1) (referindo-se a restos de campos cirúrgicos com sangue ou não) (IH 1). Ïsto vai para esta caixa!" (referindo-se ao descarte de vidros e frascos de medicamentos descartados em caixa de resíduo não contaminado. “...porque é muito pouco o que produzimos aqui...” (IH 3).

Quanto ao tipo de RSS mais citado pelos entrevistados, como sendo gerado nas respectivas áreas, o destaque ficou com o tipo não anatômico/não citotóxico, cortantes ou não, respectivamente como o primeiro mais citado em $20 \%$ das áreas, o segundo mais citado em $30 \%$ delas e o terceiro em outras $20 \%$. Este tipo de resíduo foi o segundo mais citado pelos entrevistados na listagem geral de resíduos, apresentada aos respondentes no check-list, após os resíduos do tipo comum, que ocuparam o primeiro lugar em referência.

Por esses dados, consideramos ser necessário, que as instituições de saúde tenham definido um plano de ação, iniciando pela orientação específica sobre esse tipo de 
resíduos, visando à eliminação ou minimização dos riscos à exposição dos RSS, principalmente os sabidamente contaminados, levando-se em consideração as recomendações legais existentes que apontam na direção de se ter um controle do gerenciamento destes resíduos produzidos em serviços de saúde, baseando-se, também no próprio conceito de risco de exposição a esse tipo de agente.

Pudemos, também, observar que todas as áreas selecionadas são de interesse para as ações de gerenciamento dos RSS, pelos tipos de resíduos produzidos, destacando-se, dentre essas, o Laboratório Central, Laboratório de Patologia, Salas de Parto, Radiologia e Medicina Nuclear, que devem ser consideradas como pontos de maior preocupação sanitária e ambiental no MUMC, devido às características dos resíduos gerados e não apenas pelo seu volume. Acresça-se a estas áreas também as Unidades de isolamento e de Doenças InfectoContagiosas.

\subsubsection{Fluxo dos Resíduos}

Através da observação sistematizada foram encontradas situações semelhantes em cada área selecionada nesta investigação, porém com diferentes modos de segregação, acondicionamento e armazenamento interno em algumas dessas áreas, a saber:

Foi observado que as etapas de Segregação e Acondicionamento dos RSS são realizadas, de um modo geral, de acordo com orientação do serviço contratado pela empresa hospitalar HHSC, responsável pela coleta, transporte, tratamento e destinação final dos resíduos, que segue a legislação canadense específica. Em algumas áreas selecionadas têm sido utilizados diferentes sistemas para essas etapas, destacando-se: Laboratório de Patologia, Emergência, Centro Cirúrgico e Enfermarias.

Foi observado e relatado pelo entrevistado do setor de Emergência, que há também um tipo de descarte de agulhas em um tipo de container não designado na legislação, 
em recipiente de plástico rígido, de tamanho maior do que o convencional, pelo grande volume de produção, com tampa removível, que permanece a maior parte do tempo aberta (Foto 1); outro problema levantado foi que, em algumas áreas, esses containers são super utilizados, ultrapassando a linha dos $3 / 4$ de volume, o que não é permitido pela legislação, principalmente no Centro Cirúrgico e Enfermarias.

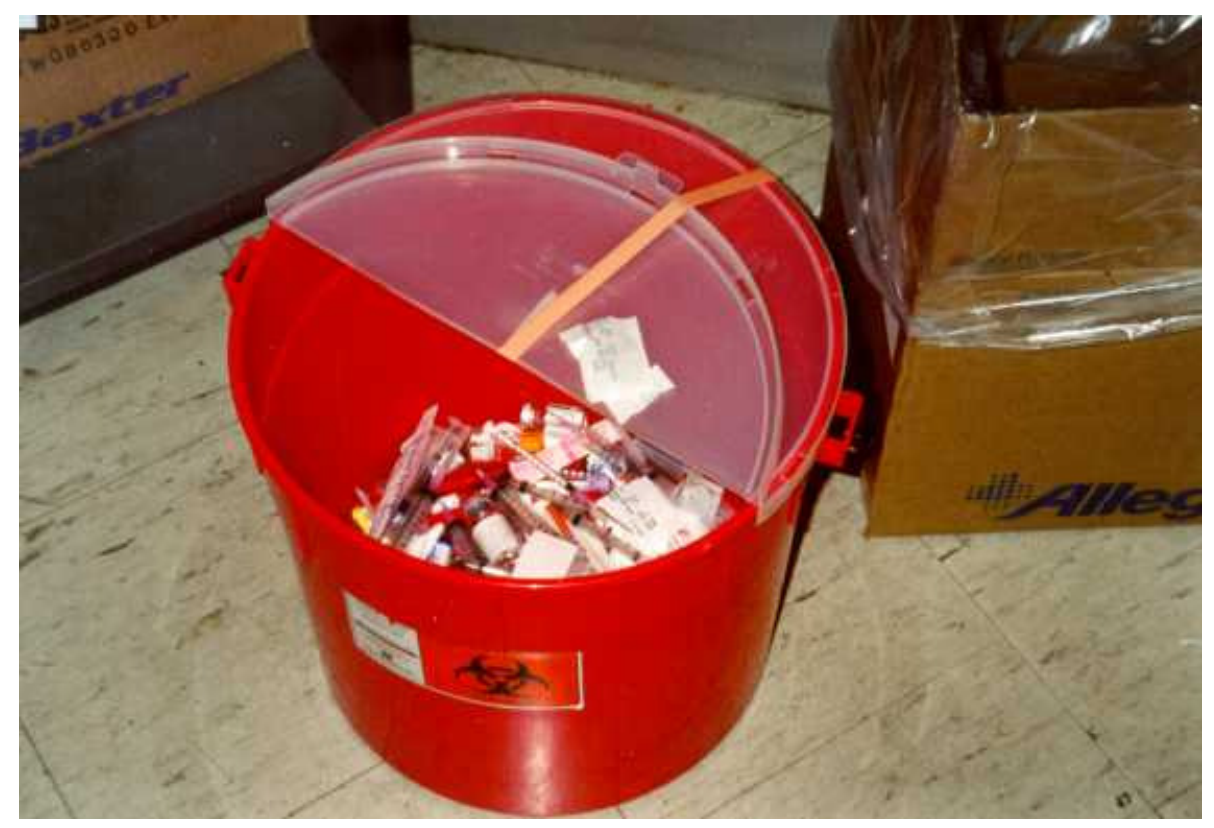

FOTO 1 - CONTAINER, COM TAMPA SOLTA, PARA MATERIAL PERFUROCTANTE PRODUZIDO NO SETOR DE EMERGÊNCIA DO MUMC. (CANADÁ, SETEMBRO, 2000)

Segundo os entrevistados, esses problemas relatados e também observados podem ser solucionados ou minimizados através de replanejamento dos instrumentos e materiais utilizados, devendo haver uma maior integração com o setor de Manutenção e Limpeza do hospital. "penso que isso (referindo-se ao tipo de embalagem para acondicionamento de RSS) deveria ser replanejado pelo setor de manutenção" (IH 7).

Sem dúvida, a questão dos equipamentos e instrumentos adequados para um melhor gerenciamento dos RSS é de fundamental importância quando se busca maior segurança e controle dos riscos ligados aos resíduos gerados em serviços de saúde. 
É igualmente importante que toda informação nesse sentido esteja atrelada a um programa de educação continuada em serviço, visando maior divulgação e participação dos geradores de resíduos no processo de seu gerenciamento.

$\mathrm{Na}$ área visitada do Laboratório Central têm sido utilizados três sacos plásticos de cor amarela para acondicionamento de materiais sabidamente contaminados, antes de serem colocados nas caixas de papelão também revestidas por outro saco plástico amarelo, utilizadas em quase todo o hospital como acondicionamento de resíduos infectantes a serem incinerados (Foto 2).
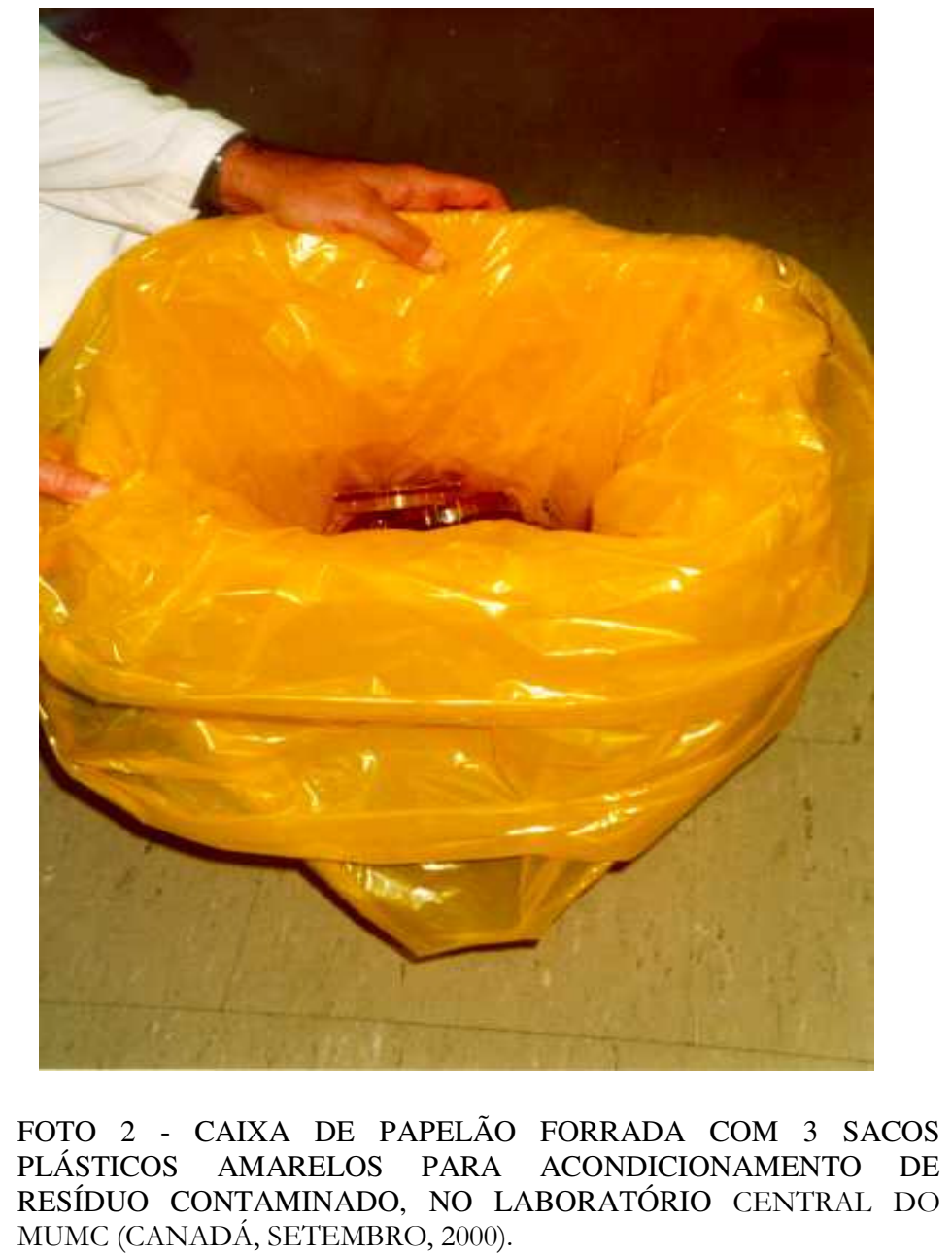

Há regras especiais editadas pelo Ministério da Saúde do Canadá para o manuseio de materiais contaminados com patógenos do Nível 3, tais como Brucella e Tuberculose, entre outros, que devem ser tratados dentro do próprio laboratório, geralmente 
em autoclaves, antes de seu descarte, e, também do Ministério do Meio Ambiente, para o manuseio de resíduos químicos perigosos (ONTARIO, 1998). Recomendação semelhante é dada pela atual RDC 33/03, no Brasil, em relação aos resíduos que sabidamente contenham patógenos do nível Classe de Risco IV, seguindo também classificação de agentes etiológicos humanos e animais da Instrução Normativa CTNBio no. 7 de 06/06/1997 (BRASIL, 2003).

De acordo com as legislações e orientações específicas do governo de Ontário, os resíduos anatômicos devem ser acondicionados em sacos vermelhos (ONTARIO, 1994); no entanto, para este procedimento no MUMC, tem sido utilizado saco plástico amarelo dentro de caixas de papelão ou de caixas de papelão ondulado mais reforçadas, com etiquetas colantes da cor vermelha, o que não foi explicado por nenhum dos entrevistados, inclusive pela gerente do setor de Manutenção e Limpeza. "eu não sei porquê" (IH 2) “...sempre foi assim...” (IH 9)

Foi observado e informado pelos entrevistados que a maioria das áreas têm problemas relativos ao Armazenamento Interno dos RSS, por inadequação do local ou falta de espaço; na Enfermaria visitada, o lixo confidencial permanece sob as bancadas de trabalho no posto de enfermagem por longo tempo até ser coletado, e, os RSS são armazenados numa pequena sala, juntamente com outros materiais sujos. Neste setor, os RSS também ficam armazenados no corredor de circulação interna.

"aqui tem muito pouca coleta; este lixo confidencial fica meses até o pessoal da manutenção vir retirar" (IH 5).

“quase não passam aqui para levar este lixo...” (IH 7).

As sugestões para solução do problema, apresentadas pelos entrevistados, foram dirigidas ao replanejamento ou revisão de novas áreas para o armazenamento interno dos resíduos gerados, juntamente com a administração geral do hospital. Outra importante observação foi que não há identificação nas portas das salas de armazenamento dos RSS, na 
maioria das áreas visitadas com sala específica, o que não requer grandes modificações ou elevado custo para o serviço implantar esta sinalização. Este é um importante aspecto gerencial dos RSS, que traz maior segurança para esse sistema.

A Coleta Interna dos RSS é feita diariamente pelos trabalhadores do setor de Manutenção e Limpeza em pequenos carros especiais, movidos à bateria, do período da manhã até a noite, durante 15 horas, aproximadamente, que coletam o lixo diretamente das áreas geradoras para o local de apresentação à coleta externa. Nem todas as áreas visitadas possuem um local exclusivo para o armazenamento interno temporário dos RSS.

O Transporte de cada tipo de lixo é feito em diferentes caixas de aço, muitas vezes transportados juntamente com resíduos de diversas origens, havendo elevadores especiais para o seu transporte (Foto 3). Não foi possível observar como esses veículos são higienizados, embora tenha sido informado pelos funcionários do setor, que os mesmos passam por higiene diária. Esses carros também não possuem símbolo de material biológico, conforme indicação da legislação canadense (CCME,1992).

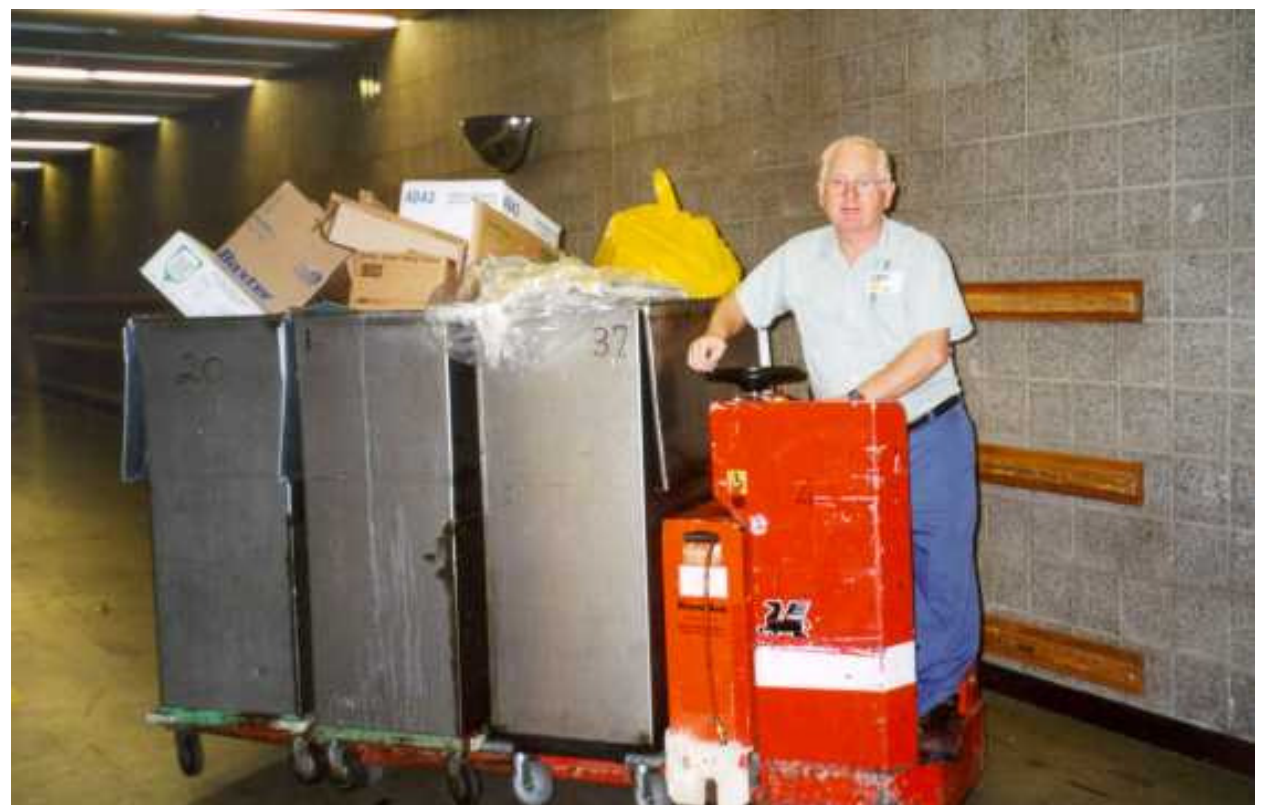

FOTO 3 - CARRO PARA COLETA INTERNA DE RESÍDUOS DE SERVIÇOS DE SAÚDE DO MUMC (CANADÁ, SETEMBRO, 2000) 
Pelo levantamento realizado junto ao MUMC, consideramos necessário manter um esquema padronizado para os diferentes tipos de resíduos e fases de seu processamento, a fim de se evitar, também, o cruzamento de lixo contaminado com não contaminado, durante o transporte e armazenamento; isto pode contribuir para que não haja um aumento do volume de resíduos que exigem maior rigor para o manuseio, o que traz, conseqüentemente, um aumento dos custos operacionais, econômicos e ambientais.

O local de Apresentação dos resíduos para coleta externa é uma área limpa, de fácil acesso para a coleta interna e externa, mas localizada no final do corredor de acesso à área de preparo de alimento, sem identificação do local, conforme exigido pela legislação e ao lado do almoxarifado e área de recepção de rouparia limpa, cujo serviço é terceirizado para empresa externa ao hospital. Também não está situado em área de acesso restrito ou continuamente controlado (Foto 4). Nesta área há um freezer trancado com cadeado, para o acondicionamento de peças anatômicas com o símbolo de risco biológico (Foto 5).

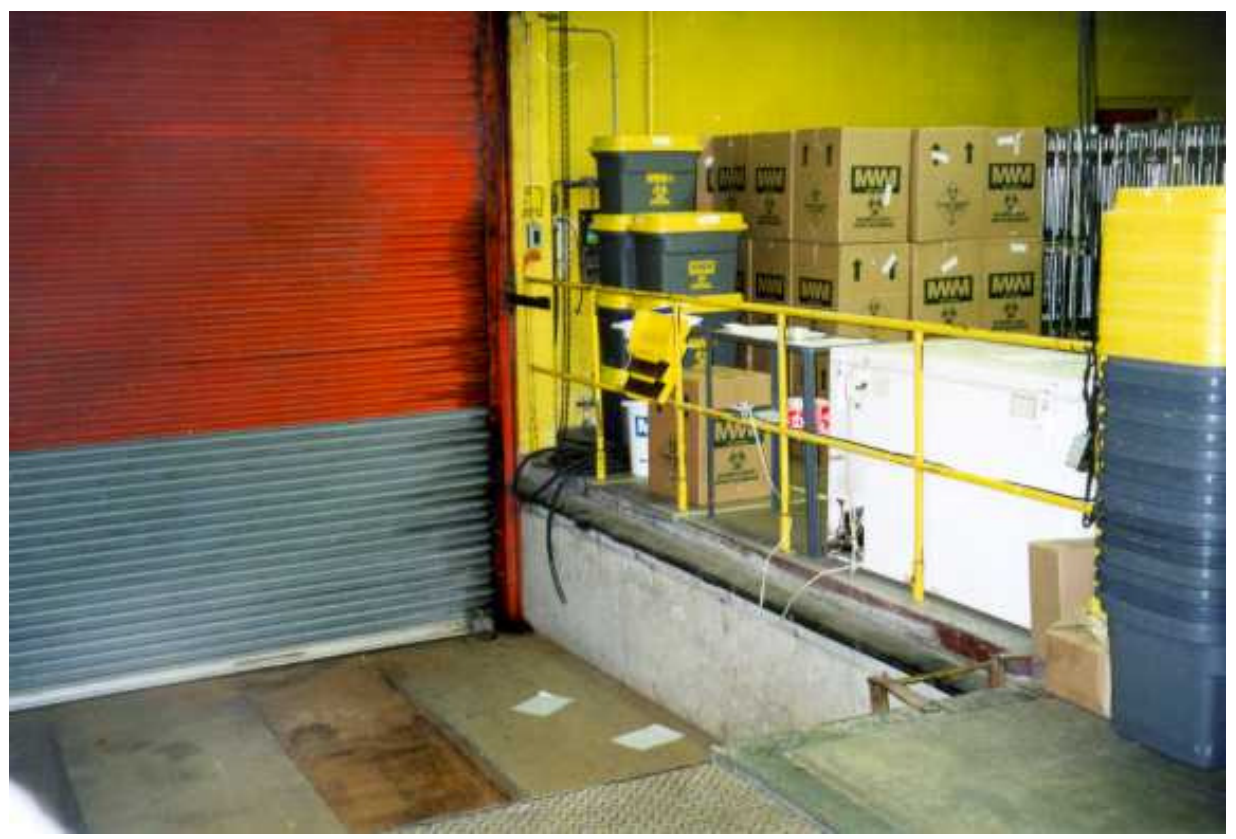

FOTO 4 - LOCAL DE ARMAZENAMENTO E APRESENTAÇÃO DOS RESÍDUOS DE SERVIÇOS DE SAÚDE DO MUMC (CANADÁ, SETEMBRO, 2000) 


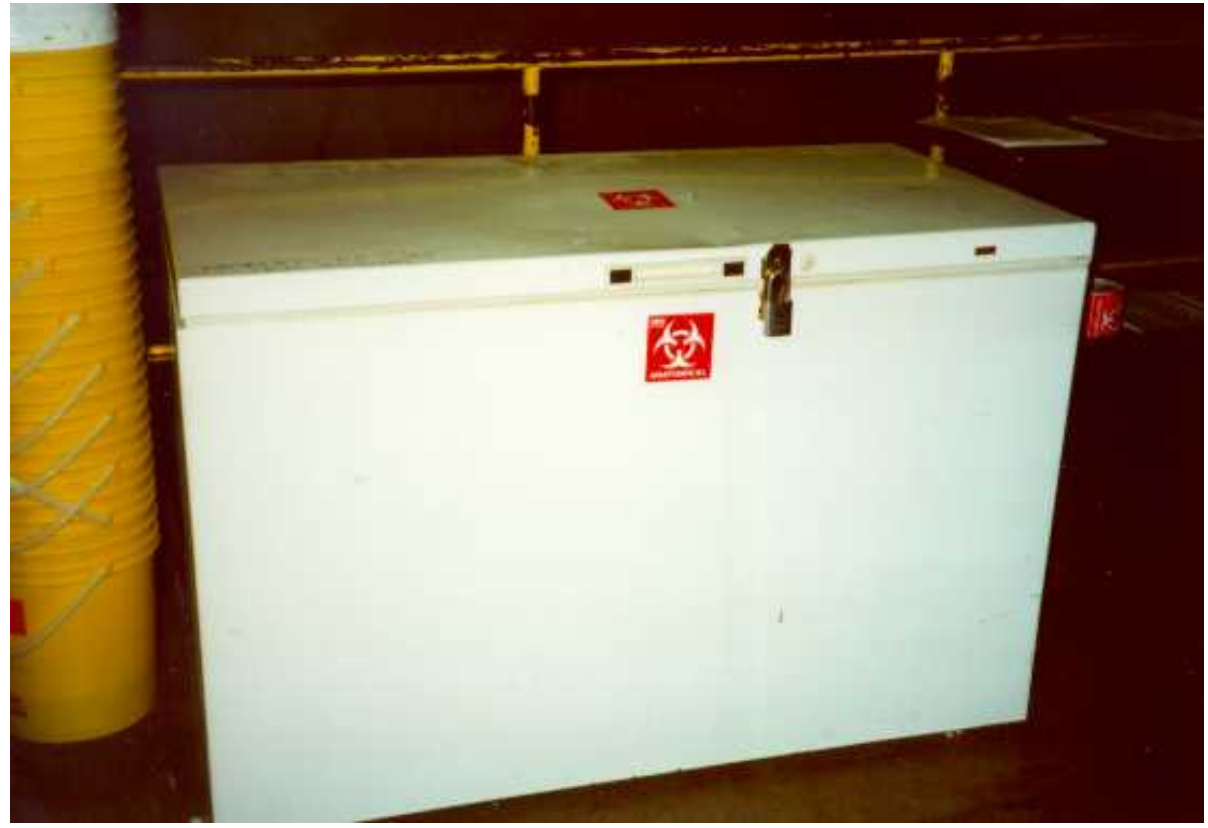

FOTO 5 - CÂMARA FRIA PARA ARMAZENAMENTO DE ANIMAIS E PEÇAS ANATÔMICAS PRODUZIDAS NO MUMC (CANADÁ, SETEMBRO, 2000)

Por estes dados observados, consideramos ser importante e necessário a identificação dos locais de armazenamento de resíduos com etiquetas indicativas da área e do serviço, além de um maior controle do acesso de estranhos ao setor, por questão de segurança.

Os RSS produzidos no MUMC, após serem coletados pela empresa contratada, o que é realizado três vezes por semana, são enviados para Tratamento e Disposição Final. Os tipos de resíduos, tais como: os potencialmente infecciosos, sangue e derivados, ou material sujo com sangue ou fluidos corporais, agulhas e todo tipo de resíduo acondicionado em containers reutilizáveis recebem tratamento em autoclave. Os resíduos do tipo anatômicos, cito-tóxicos e químicos (incluindo-se todo material contaminado com esses produtos), acondicionados em containers descartáveis, são enviados para incineração nos Estados Unidos (cerca de $200 \mathrm{~km}$ de distância da fonte geradora).

A Figura 2 abaixo apresenta os diversos passos do processamento dos diferentes tipos de resíduos gerados no MUMC, desde suas fontes geradoras até a disposição final, bem como as empresas responsáveis por cada tipo de resíduo: 


\begin{tabular}{|c|c|c|c|}
\hline TIPOS DE RESÍDUOS & EMPRESA & TRATAMENTO & DISPOSIÇÃO FINAI \\
\hline $\begin{array}{l}\text { DE SERVIÇOS } \\
\text { DE SAÚDE }\end{array}$ & MWM -Inc. & $\begin{array}{l}\text { •AUTO CLAVE } \\
\text { •INCINERAÇÃO }\end{array}$ & ATERRO SANITÁRIO \\
\hline COMUM & PREFEITURA -SWARU & INCINERAÇÃO* & ATERRO SANITÁRIO \\
\hline PERIGOSO & HOTZ - COMP. & RECICLAGEM & $\begin{array}{l}\text { ATERRO } \\
\text { SANITÁRIO**** }\end{array}$ \\
\hline RADIOATIVO & McMaster-UNIVERSITY & ARMAZENAMENTO $* *$ & ATERRO SANITÁRIO \\
\hline RECICLAVÉL & THIRD SECTOR & RECICLAGEM & ATERRO SANITÁRIO \\
\hline $\begin{array}{l}\text { MÓVEIS/ } \\
\text { EQUIPAMENTOS }\end{array}$ & $\begin{array}{l}\text { •DOAÇÃO } \\
\text { •PREFEITURA }\end{array}$ & & $\begin{array}{l}\text { •RE-USO } \\
\text {-ATERRO } \\
\text { SANITÁRIO *** }\end{array}$ \\
\hline $\begin{array}{l}\text { * *USINA DE RECUPERAĈ̃AO } \\
* * \text { *TÉ O TEMPO DA MEIA-VI } \\
* * \text { ATERRO SANITÁRIO ESSE }\end{array}$ & $\begin{array}{l}\text { E ENERGIA } \\
{ }_{\mathrm{AL}}\end{array}$ & & \\
\hline
\end{tabular}

Através da Figura 2 acima podemos também observar que todos os resíduos gerados em cada área têm a mesma disposição final, independente de terem recebido algum tipo de tratamento. Isto nos remete para uma reflexão sobre a necessidade de se promover nos serviços de saúde, tanto os esforços direcionados à minimização dos problemas ligados aos RSS, quanto o alcance de novas práticas mais sanitárias e ecológicas em relação ao gerenciamento dos resíduos produzidos nesse setor.

Além disso, é necessário, também, manter adequadas condições físicas e materiais no serviço, para dar suporte às diferentes fases do manuseio dos RSS, como no acondicionamento, transporte e armazenamento, promovendo ampla discussão entre trabalhadores e lideranças de cada área, no sentido de identificar os perigos em potencial dos resíduos gerados, seja através de grupos organizados ou no cotidiano das atividades, a fim de identificar alguma falha no processo e propor possíveis mudanças. 


\section{CONSIDERAÇÕES FINAIS}

Este estudo nos permite fazer algumas considerações sobre o sistema de gerenciamento dos RSS no MUMC, baseados na observação do investigador e nas informações obtidas com as entrevistas, trazendo um recorte da situação desse tipo de gerenciamento no Canadá, em situação operacional que guarda similaridades com instituições hospitalares brasileiras, não havendo significativa diferença entre os resíduos de serviços de saúde produzidos, tanto no hospital selecionado no Canadá, quanto nos serviços hospitalares no Brasil, em termos de sua natureza e constituição.

A diferença que encontramos através desta pesquisa localiza-se na questão da forma como os RSS têm sido gerenciados no MUMC, comparando-se ao tipo de gerenciamento existente em instituição hospitalar semelhante no Brasil (TAKAYANAGUI, 1993), que segue diferentes orientações baseadas em uma classificação não tão específica como as legislações canadenses (CCME,1992: ONTARIO, 1994 e 1998).

Certamente a acurácia dos dados está diretamente ligada ao contexto desta investigação, o que significa que podem ser encontrados na instituição pesquisada alguns outros eventos ou fatos não revelados neste estudo. No entanto, foi possível elaborar um perfil da situação do gerenciamento dos RSS junto ao MUMC, atingindo os objetivos inicialmente propostos, o que revelou que, em termos gerais, todos os tipos de RSS listados pelas legislações federal e provincial canadenses têm sido produzidos nas diferentes áreas selecionadas daquele hospital. 
Pôde-se perceber que o MUMC possui uma infra-estrutura suficientemente organizada para manter um adequado sistema de gerenciamento dos RSS, embora tenham sido detectados alguns problemas, principalmente em relação a atitudes e entendimentos dos trabalhadores quanto ao manuseio e descarte destes resíduos. Os principais pontos de vulnerabilidade identificados situam-se nas fases de segregação, acondicionamento e armazenamento interno dos RSS gerados naquela instituição hospitalar, o que, a nosso ver, fundamenta-se na ausência da definição de lideranças com a responsabilidade direta pelos RSS nas áreas pesquisadas.

Vale nos reportar a alguns estudos que destacam a importância de um sistema definido de responsabilidades e gerência dos RSS nos serviços, a exemplo do que há, tanto na legislação canadense, quanto na brasileira. Um outro aspecto diz respeito a novos tipos de resíduos que vêm ganhando espaço na academia, nessa área do conhecimento, pelo impacto à saúde da equipe desses setores, que vêm sendo detectado em estudos nos últimos anos. Tratase de resíduos gerados em serviços de pré-anestesia ou em salas de cirurgia, com a emissão de importantes gases anestésicos como o óxido nitroso, desflurane, isoflurane e halotane, causando alterações cromossômicas e danos genotóxicos (SESSLER \& BADGWELL, 1998).

As soluções para tais problemas demandam ações mais sistematizadas para a difusão de normas e procedimentos, de acordo com a legislação do país e da província de Ontário, sem grande ônus para o serviço. De acordo com informação da gerência do setor de Manutenção e Limpeza, está em fase de planejamento e início de implantação em algumas áreas, do hospital pesquisado, de um programa de orientação específica visando difundir normas para manuseio dos RSS, seguindo a legislação específica, que considera "não prático ou necessário tratar todo tipo de resíduo como RSS” (CCME, 1992, p.3).

Por outro lado, embora este conceito esteja fundamentado na preocupação com a situação da poluição ambiental, o mesmo pode, igualmente, representar uma ameaça tanto à 
saúde humana quanto ao ambiente, se os RSS forem manuseados inadequadamente. É necessário que todo gerador de RSS esteja adequadamente informado e conscientizado sobre a questão, para realizar todos os passos de seu processamento de modo seguro.

$\mathrm{Na}$ fase final da coleta de dados desta investigação acadêmica, pudemos observar que o setor de Manutenção e Limpeza do MUMC havia iniciado a identificação de alguns pontos de armazenamento interno de resíduos, o que ocorreu aproximadamente um mês após o início das entrevistas, que geraram diversas indagações sobre as questões referentes ao processamento dos RSS naquela instituição, mostrando que é possível promover ações voltadas para a organização dos serviços com o envolvimento dos trabalhadores e da administração.

Assim, é de fundamental importância que todo estabelecimento gerador tenha um programa de educação continuada em serviço que se mantenha constantemente em atividades de difusão das regras e normas específicas, promovendo maior conscientização e envolvimento responsável dos geradores. Outro importante aspecto diz respeito ao papel de uma liderança em cada setor, que seja capaz de responder pelo gerenciamento dos RSS, de modo a garantir maior eficiência de seu processamento em todas as fases de manuseio e descarte.

Esta atividade poderia ser liderada pelo setor de Manutenção e Limpeza, juntamente com os gerentes de resíduos de cada setor, proposição esta, que ficou evidente nas respostas dos entrevistados, através do posicionamento de cerca de $50 \%$ deles, que sugeriram maior integração e um contato mais próximo de cada área do hospital com o setor de Manutenção e Limpeza do MUMC. Sem dúvida, quando presente uma gerência geral de RSS numa instituição de saúde do porte do MUMC, há que se propiciar a formação de lideranças articuladas com essa gerência, de modo que permaneça uma coordenação e integração das ações gerenciais voltadas para esses resíduos. 
Embora não tenha sido nosso objetivo, consideramos ter percorrido, com esta investigação, alguns passos do processo de Avaliação de Risco por RSS, o que representa uma importante contribuição para os tomadores de decisão, na inserção do gerenciamento de risco nas ações administrativas dos serviços de saúde. Consideramos que, no caso dos RSS, poderia ser utilizada essa estratégia metodológica, com esquema adaptado do modelo proposto pela Associação de Padronização Canadense (NATIONAL..., 1997 a), a saber:

\begin{tabular}{|l|l|}
\cline { 2 - 2 } \multicolumn{1}{c|}{} & IDENTIFICAÇÃO DO RISCO \\
\hline AVALIAÇÃO DE RISCO & \\
\hline \multirow{2}{*}{ ANÁLISE DO RISCO } \\
\hline
\end{tabular}

\begin{tabular}{|l|l|}
\cline { 2 - 2 } \multicolumn{1}{c|}{} & OPÇÕES ALTERNATIVAS \\
\hline GERENCIAMENTO DE RISCO & ANÁLISE DAS OPÇÕES \\
\hline & $\begin{array}{l}\text { IMPLEMENTAÇÃO E AVALIAÇÃO } \\
\text { DAS OPÇÕES }\end{array}$ \\
\hline
\end{tabular}

Especificamente para este estudo, foi possível identificar o risco representado pelos diferentes tipos de resíduos gerados na instituição, referidos pelos informantes, bem como procedermos ao início da análise desses riscos, identificando os principais pontos de produção dos RSS e as lideranças diretamente ligadas à esta questão, significando importantes elementos para o setor de planejamento e administração do MUMC. Obviamente, a utilização desse instrumento gerencial por completo exigiria um desenho metodológico diferente do adotado em nossa investigação.

Nesse sentido, consideramos viável e importante a inclusão da estratégia de Avaliação de Risco por exposição a resíduos gerados em serviços de saúde, bem como da 
estratégia de Gerenciamento de Risco, promovendo a adoção de novas abordagens metodológicas no campo da saúde ambiental, especificamente para o processo de avaliação e gerenciamento dos serviços de saúde.

Quando se compara a situação gerencial dos RSS, nos aspectos legais, vale lembrar que, no Brasil, até a metade da década de 90, segundo diversos estudos e documentos, havia diferentes classificações e nomenclaturas para resíduos de serviços de saúde (MOREL, 1992; BERTUSSI FILHO, 1985). Ultimamente, os governos federal e estadual editaram orientações legais trazendo novas classificações para os RSS, o que representa um importante passo para um melhor gerenciamento destes resíduos (BRASIL, 1993, 2001 e 2003; SÃO PAULO, 1998), apesar da controvérsia existente em relação a esse tema.

Já, no Canadá, há uma legislação muito mais ampla e específica sobre esta questão, ao contrário do Brasil, que possui normas e regulamentos não tão específicos, surgidos mais recentemente; diferentemente daquela realidade, não há no Brasil orientações legais tão claras e profundas sobre o manuseio, tratamento e disposição final de RSS, como se encontra no Canadá.

No Brasil, apenas em 1993, o Ministério do Meio Ambiente editou uma nova Resolução (Res.CONAMA no.5/93), após um longo período praticamente sem orientação legal mais específica, tanto para as instituições geradores, como para aquelas responsáveis pela coleta, tratamento e destinação final, mas, ainda não suficiente para dar todas as diretrizes necessárias aos geradores sobre o gerenciamento desses resíduos.

Por outro lado, no Canadá, há uma extensiva orientação sobre os passos do gerenciamento dos RSS dentro e fora das instituições geradoras, além de diferentes orientações principalmente para o manuseio, segregação e acondicionamento dos diversos tipos de resíduos gerados nos estabelecimentos de saúde. Um exemplo do rígido controle dos RSS é a exigência dos chamados "Manifests", que são os formulários de registro de todas as 
ocorrências com um resíduo, desde o momento de sua geração até o tratamento e destinação final, com extremo controle por parte das autoridades sanitárias e dos responsáveis pelos resíduos, que são também, como no Brasil, os proprietários ou gerentes/diretores dos estabelecimentos de saúde.

Esta pesquisa não teve o objetivo de analisar completamente ambos os sistemas, canadense e brasileiro, de gerenciamento de RSS, nem de apontar para o melhor ou pior dentre os dois; porém, nos permite fazer uma avaliação geral de alguns aspectos ligados a essa questão, trazendo importantes tópicos para discussão.

Semelhante ao Brasil, o Canadá tem uma legislação nacional sobre gerenciamento de RSS (CCME,1992) e orientações legais específicas dos governos das províncias e municípios, que trazem, as vezes, diferentes opções para seu manuseio e tratamento (NATIONAL..., 1991); este sistema já vem ocorrendo há mais de duas décadas, com revisões periódicas da legislação.

Atualmente, no Brasil está ocorrendo uma intensa discussão em torno das novas exigências legais propostas pela ANVISA (BRASIL, 2003), que passou a exigir ações muito diferenciadas das até então existentes, principalmente para o manuseio, acondicionamento e tratamento dos diferentes tipos de resíduos gerados na área da saúde.

Isto, por um lado, traz benefício pela difusão do assunto, porém, essa situação tem gerado insegurança e dúvida por parte de geradores e mesmo dos agentes fiscalizadores, principalmente porque essa nova legislação se baseia em concepções de sua periculosidade muito diferentes das que direcionavam as normas anteriores; e, também, pela complexidade de suas exigências, o que vai de simples ações no ponto de geração a mudanças do sistema de tratamento e disposição final, implicando em altos investimentos do setor público e mesmo do privado, uma vez que a maior parte dos RSS do Brasil é despejada a céu aberto sem qualquer tipo de tratamento prévio. 
A definição de RSS adotada pela legislação nacional de ambos os países é praticamente a mesma, diferindo nos aspectos concernentes à classificação destes resíduos. Este é um importante ponto que afeta diretamente as normas sobre manuseio, segregação, acondicionamento e tratamento dos RSS, o que justifica a variedade de opções para segregação, acondicionamento e tratamento, adotadas pelo MUMC.

Porém, isto não significa que não haja problema relativo aos RSS na instituição de saúde canadense, onde também tem ocorrido um importante movimento da sociedade em relação à instalação de novos aterros sanitários ou incineradores ou, ainda, com a qualidade e condições de uso e descarte de seus equipamentos de radiologia, demonstrando que a população está cada vez mais participativa e preocupada com estas questões ambientais, principalmente com aquelas causadas pelo lixo urbano gerado (MENTEK, 2000).

Nesta investigação foi constatado que nem todas as áreas estudadas manuseiam os resíduos seguindo todas as normas legais. Isso pode estar fortemente relacionado a um desconhecimento por parte dos geradores sobre a importância e periculosidade dos RSS.

Portanto, os achados desta investigação confirmam nosso pressuposto de que, apesar do diferencial legal existente, em relação ao manuseio e gerenciamento dos RSS no Canadá, em relação ao Brasil, há uma similaridade no comportamento dos geradores entre ambas as realidades envolvidas. Isto, a nosso ver, significa que não bastam apenas normas e exigências legais para se garantir um adequado sistema; é preciso, primeiro, o incentivo e valorização da gerência sobre essa questão, promovendo o desenvolvimento de programas educativos contínuos em serviço, com avaliações e seguimento da situação de cada área, envolvendo todo o pessoal dos diferentes setores da instituição.

De um modo geral, apesar do evidente aumento da discussão sobre gerenciamento de resíduos e da própria questão ambiental, há ainda poucas propostas concretas lançadas na sociedade atual, e a humanidade ainda não encontrou uma solução 
mágica para solucionar os problemas causados pelo lixo que o próprio homem produz nas suas atividades cotidianas. O mesmo tem ocorrido nas instituições de saúde, que cada vez mais vem aumentando o volume de resíduos, principalmente após o rápido aparecimento de embalagens e produtos descartáveis nas últimas décadas.

Não há dúvida de que todos os tipos de bens produzidos pela humanidade retornarão, algum dia, para o solo ou para cursos d'agua, mas muito provavelmente estarão totalmente modificados pela industrialização, o que representa um dos maiores problemas de poluição.

Em se tratando dos resíduos gerados nos serviços de saúde, além da preocupação ambiental, há a questão do risco à saúde humana por exposição a agentes de origem biológica, destacando-se dentre estes os infecciosos, como os vírus HIV, HBV e HCV, aos agentes de origem química e radioativa, que têm uma maior chance de estarem presentes nestes resíduos (DE NAEYER \& DE BOEVER, 1995). Portanto, as relações entre ambiente e saúde estão intrinsecamente associadas à relação de risco, constituindo-se num objeto de grande complexidade.

Para isso, há que se tomar novas medidas para a promoção da saúde pública a partir de melhores condições do ambiente físico do trabalho, que podem ser trazidas de novos paradigmas existentes na administração dos serviços de saúde.

Adicionalmente, é necessário compreender que "as estruturas, processos e resultados desses serviços estão inseridas num contexto dinâmico que demanda novas abordagens de investigação" (RUNDALL et al., 1999, p. 1091). Assim, essa proposta de gerenciar os RSS, iniciando-se por conhecer os principais pontos de produção e os diferentes tipos de resíduos em cada setor pode ser um importante instrumento de avaliação de risco de exposição a esses agentes. 
Não há no Brasil e também não encontramos no Canadá um protocolo instituído para um inventário sobre a situação dos RSS, incluindo-se os demais tipos de resíduos sólidos gerados nas instituições hospitalares, de modo a facilitar o processo de Avaliação e Gerenciamento de Risco por estes agentes, presentes no ambiente de saúde, do tipo hospitalar ou ambulatorial.

Existe no Brasil um roteiro para a elaboração de um Plano de Gerenciamento de RSS, que está em fase de implantação no Estado de São Paulo (SÃO PAULO, 1998), mas com abrangência um pouco extensa para facilitar o seu uso no cotidiano.

Assim, a partir de nossa experiência com essas investigações na área de RSS, apresentamos um protocolo para avaliação de risco por RSS nos serviços de saúde, visando à proposição da inclusão do processo de Avaliação e Gerenciamento de Risco para os sistemas de gerenciamento dos resíduos gerados nos serviços de saúde, a fim de se obter uma melhor organização dos serviços e, ao mesmo tempo, contribuir para melhores condições ambientais e sanitárias dos serviços de saúde.

\subsection{Protocolo para Avaliação de Risco por RSS}

Independentemente das diferenças existentes entre serviços de saúde, podemos elaborar um protocolo a ser aplicado como estratégia auxiliar para o gerenciamento de RSS, que se constitui num útil instrumento para os administradores e tomadores de decisão da área hospitalar, tais como dos setores: de manutenção e limpeza, de enfermagem, de controle de infecção, de engenharia de segurança e serviços gerais e de saúde ambiental, dentre outros que freqüentemente recebem a designação para o controle destes resíduos.

Consideramos como passos básicos, a identificação do risco de exposição causada por diferentes agentes que podem ser encontrados nos RSS, tais como os de origem 
biológica, química e radioativa. Para isso é fundamental que se conheça os tipos de resíduos gerados na instituição, bem como as áreas em que são produzidos.

Evidentemente, este passo inicial deve estar baseado na classificação dos RSS ditada pela legislação vigente, de forma a permitir a elaboração de uma listagem dos resíduos gerados em cada área, bem como um mapeamento dos locais onde são produzidos cada tipo de resíduo, visando ser amplamente utilizado e compreendido por qualquer profissional envolvido com a questão.

A análise de cada fase do processamento dos resíduos gerados nas respectivas áreas do serviço de saúde deve estar diretamente ligada ao conceito de risco de exposição a agentes perigosos, tanto para os pacientes quanto para os trabalhadores da instituição. Além dos riscos para a saúde humana, há que se considerar também os riscos ambientais referentes à poluição do ar, da água e do solo, dependendo da forma como são manipulados, tratados e dispostos no final do processo.

Quando se pretende aplicar a estratégia de Avaliação de Risco para os RSS em instituições de saúde, pode-se utilizar um protocolo que facilite o processo de avaliação da situação, visando reunir subsídios para o planejamento de ações voltadas para a solução dos problemas levantados, o que dá condições para uma melhor visualização da situação existente. Procedendo sua aplicação são necessários os seguintes pré-requisitos:

Pré-requisitos para uso da estratégia de Avaliação de Risco por RSS:

1. Identificar as legislações e normas legais no nível federal, estadual e municipal sobre RSS. 2. Nos locais onde não exista uma orientação legal clara e específica, é preciso, primeiramente, que sejam definidas regras para classificação, segregação, acondicionamento, coleta, transporte, armazenamento, tratamento e disposição final para os resíduos. 
3. Identificar todas as áreas da instituição que estejam envolvidas com ensino, pesquisa e assistência e trabalhando com saúde humana ou animal. Isto pode ser obtido através de visitas ou incursões do investigador nos diversos setores do serviço, por um tempo tão longo quanto este julgar necessário.

4. Identificar todos os tipos de resíduos que têm sido gerados em cada área com a colaboração de lideranças da área ou setor. É importante que as informações não se restrinjam às informações relatadas em entrevistas formais ou informais, mas que seja também utilizada a observação sistematizada e outros informantes secundários ou grupos de apoio. Pode-se também lançar mão de figuras ou ilustrações dos diferentes tipos de RSS e de embalagens, além de formulários/roteiros auxiliares para as entrevistas, abordando todas as fases do processamento desses resíduos.

5. Identificar os principais problemas referentes aos resíduos gerados em cada área, de acordo com a percepção de lideranças, o que pode facilitar a avaliação de risco dos RSS na instituição.

6. Elaborar um mapa das principais áreas de risco à exposição de RSS em cada área da instituição, a fim de tornar visível o levantamento e contribuir para uma efetiva conscientização de todos os trabalhadores.

7. Promover eventos para orientação, divulgação, comunicação informal, grupos de discussão, programas de educação continuada e as mudanças necessárias relativas ao gerenciamento de RSS, visando minimizar os riscos e alcançar um ambiente de trabalho mais seguro e saudável.

Embora esta atividade de avaliação necessite da colaboração de lideranças de cada área, é uma tarefa que depende bastante do conhecimento e do bom senso do auditor, que deve pesquisar pessoalmente cada ponto a ser analisado e não basear-se apenas nas informações obtidas pelos respondentes de cada área. 
É importante que se mantenha um contato mais próximo com administradores ou gerentes da instituição antes da aplicação de um protocolo, a fim de facilitar a identificação de lideranças em cada área e o seu planejamento e utilização. Após a aplicação de protocolo e organização das informações, pode-se obter um importante documento a ser utilizado como ponto de partida para os administradores e tomadores de decisão, no processo de gerenciamento dos RSS em instituições hospitalares, considerando a complexidade dos sistemas institucionais de saúde que estão sofrendo mudanças cada vez mais rápidas.

Assim, nossa proposição é de um protocolo, como o utilizado nesta investigação, que possa ser aplicado em diferentes tipos de serviços de saúde, visando à obtenção de dados sobre a forma como os RSS têm sido gerenciados na instituição, destacando os tipos de resíduos gerados e mapeando os principais pontos geradores. $\mathrm{O}$ documento deve abordar todos os passos do processamento dos RSS, desde a sua produção até a destinação final, podendo ser modificado de acordo com as necessidades de cada setor pesquisado.

Há que se considerar que toda e qualquer mudança requer um tempo para assimilação e incorporação de novos direcionamentos, implicando na necessidade, primeira, de internalização, por parte dos envolvidos, dos aspectos que se quer abordar ou implantar num serviço. E isso deve ser parte inserida no processo de educação, que permita a compreensão e o estímulo do pessoal para a mudança que se almeja.

Finalmente, deve-se buscar uma forma de disciplinar todo o processo de trabalho relativo ao gerenciamento dos RSS, tomando-se por base a necessidade de implementação de políticas públicas mais decisivas e compromissadas com a adoção de novas tecnologias e diretrizes técnico-operacionais, no sentido de colaborar para a construção de um ambiente ecologicamente adequado e de uma melhor qualidade de vida. 


\section{REFERÊNCIAS}

ABNT (ASSOCIAÇÃO BRASILEIRA DE NORMAS TÉCNICAS). NBR. 10.004: Resíduos sólidos: classificação. Rio de Janeiro: ABNT, 1987.

ALLERMANN, Leila; POULSEN, Otto M. Inflammatory potential of dust from waste handling facilities measured as IL-8 secretion from lung epithelial cells in vitro. The Annals of Occupational Hygiene, v.44, n. 4: 259-269, Jun., 2000. Disponível em http://www.sciencedirect.com/science. Captada em 14/06/2000 14:42.

ALVARENGA, T. A agenda do futuro. Veja, p.56-63, 22 abr. 1992.

BARDIN, L. Análise de conteúdo. Edições 70. Tradução de Luiz Antônio Reto e Augusto Pinheiro. Lisboa, 1979. 229 p.

BAXTER, Jamie W.; EYLES, John D.; ELLIOTT, Susan J. From siting principles to siting practices: a case study of discord among trust, equity and community participation. Journal of Environmental Planning and Management, v.42, n.4: 501-525, 1999 a.

BAXTER, Jamie W.; EYLES, John D.; ELLIOTT, Susan J. 'Something happened': the relevance of the risk society for describing the siting process for a municipal landfill. Geografiska Annaler. 81 B, n.2: 91-109, 1999 b.

BERTUSSI FILHO, L. A. Lixo hospitalar: higiene ou matemática. Contr. Infec., v.2, n. 6: 3-4, 1988.

BLENKHARN, J. I. The disposal of clinical wastes. J. Hosp. Infect., v.30: 514-20, 1995. (Suppl)

BOCKHOLD, Kathleen M. Who's afraid of Hepatitis C? AJN, v. 100, n.5: 26-32, May 2000. 
BRASIL, 1993. Resolução ${ }^{\circ} 05$ de 5 de agosto de 1993. Define os procedimentos básicos relativos ao gerenciamento de resíduos sólidos de serviços de saúde. Diário Oficial da União. Brasília, DF, p.12.996, 31 de agosto de 1993. Seção 1.

Resolução CONAMA n ${ }^{\circ}$. 283, de 12 de julho de 2001. Dispõe sobre o tratamento e destinação final dos resíduos sólidos. Diário Oficial da República Federativa do Brasil, Brasília, 01 out 2001. Seção I, p. 12996.

Resolução ANVISA no . 33, de 25 de fevereiro de 2003. Dispõe sobre o regulamento técnico para o gerenciamento de resíduos de serviços de saúde. Diário Oficial da República Federativa do Brasil, Brasília, $05 \quad$ mar $3 . \quad$ Disponível em: <http://www.anvisa.gov.br/legis/resol/2003/rdc/33_03rdc.htm> Acesso em: 10 de março de 2003.

BORJA-ABURTO, Víctor Hugo; BERMÚDEZ-CASTRO, Oscar; LACASAÑA-NAVARRO, Marina e cols. Dificultades en los métodos de estudio de exposiciones ambientales y defectos del tubo neural. Salud Pública Méx., v. 41: 34-41, 1999. (supl.2)

BROWN, L. Working for a health environment. RNABC News, v.22, n.2 : 21-4, 1990.

BROWN, P. Popular epidemiology and toxic waste contamination: lay and profesional ways of knowing. Journal of Health and Social Behavior, v. 33: 267-281, 1992.

CALDERON, R.L. Measuring risks in humans : the promise and practice of epidemiology. Food Chem.Toxicol, n.38: S59 - 63, 2000. (1 Suppl)

CANADA. Minister of Supply and Services Canada. Health-Risk perception in Canadá - a research report to the Department of National Health and Welfare.Queen's Printer for Ontario, Toronto. 93-EHD - 170, 1993.

CANADA. Health Canada. Proceedings of the consensus conference on infected health care workers: risk for transmission of bloodborne pathogens. Canada Communicable Disease Report, v. 24S4, Jul.1998. Supplement. Disponível em: http://www.hcsc.gc.ca/hpb/lcdc/publicat e acessado em 7/9/00 6:27.

CCME (CANADIAN COUNCIL OF MINISTERS OF THE ENVIRONMENT). Guidelines for the management of biomedical waste in Canada. Winnipeg. Canadian Standards Association, CCME EPC-WM-42 E, 1992. 
COIMBRA, J.A.A. O outro lado do meio ambiente. São Paulo, CETESB/ASCETESB, 1985.

COLE, Donald. Risk assessment- some frameworks. MacMaster University. Environmental Health Program.Working Paper Series 3, Risk Assessment Workshop. Waterloo, Canada. p.4-11, 1995.

COLE, Donald; URSITI, F.; SIDER,D. How does it fit in with risk perception, risk communication and risk management? MacMaster University. Environmental Health Program.Working Paper Series 3, Risk Assessment Workshop. Waterloo, Canada. p.2-82, 1995.

COLE, Donald C.; PENGELly, David; EYleS, John; STIEB, David M.; HUSTLER, Rhonda. Consulting the community for environmental health indicator development: the case of air quality. Health Promotion International, v.14, n.2: 145-154, 1999.

COULTER, M. L. \& NOSS, C.I. Preventative social work in perceived environmental disasters. Health and Social Work, v.13:296-300, 1988.

DALEY, K. Introduction of health care worker needlestick and sharps injury prevention act [statement]. American Nurses Association Press Releases. May, 1999. Disponível em http://www.nursingworld.org/pressrel/1999/st0520.htm. Captado em 17/4/2000 9:31.

DE NAEYER K; DE BOEVER J. The problem of cross infection and risk of infection for the practitioner. Rev. Belge Med. Dent., v.50, n.1:19-33, 1995.

DRIVER, I.; PACKER, S. Radioactive waste discharge quantities for patients undergoing radioactive iodine therapy for thyroid carcinoma. Nucl. Med. Commun, v.22, n.10:1129-32, 2001.

DUNN, Ferri C.P. Epidemiological methods for research with drug misusers: review of methods for studyng prevalence and morbidity. Rev. Salud Publica. v.33, n.2: 206-215, Apr., 1999.

EDULJEE, G.H. Trends in risk assessment and risk management. Sci.Total Environ., n. 17, n. 249 (1-3):13-23, Apr. 2000. 
ELLIOTT, Susan J.; MARTIN TAYLOR, S.; WALTER, Stephen; STIEB, David; FRANK, John; EYLES, John. Modeling psychosocial effects of exposure to solid waste facilities. Social Science and Medicine, v.37, n.6: 791-804, 1993.

ELLIOTT, Susan J.; MARTIN TAYLOR, S.; HAMPSON, Christine; DUNN, James; EYLES, John; WALTER, Stephen; STREINER, David. 'It's not because you like it any better...': residents'reappraisal of a landfill site. Journal of Environmental Psychology, v.17: 229-241. 1997.

ELLIOTT, Susan J. A comparative analysis of public concern over solid waste incinerators. Waste Management and Research, v. 16, n. 4: 351-364, 1998.

ELliOTT, Susan J.; COLE, Donald C.; KRUEGER, Paul; VOORBERG, Nancy; WAKEFIELD, Sarah. The power of perception: health risk attributed to air pollution in an urban industrial neighbourhood. Risk Analysis, v.19, n. 4, 1999.

ELWOOD, M. Critical appraisal of epidemiological studies and clinical trials. Oxford: Oxford University Press, $2^{\text {nd }}$. ed. 1998.

EYLES, John. Evaluating risk: assessment, perception and communication. MacMaster University. Environmental Health Program. Proceedings, Working Paper Series 1, Risk Communication Papers and Workshop. Guelph, Canada. p.14-25, 1994.

EYLES, John. Where we say we are: a partial account of a partial of social science in relation to environmental health. Environmental Health Program, McMaster University/Great Lakes Health Effects Program, Health Canada. Workshop Proceedings, 6, Social Science Approaches to Environmental Health in the Great Lakes Ecosystem. Hamilton, Canada. p. 5$18,1995$.

EYLES, John; ELLIOTT, Susan; GRONDIN, Jacques; SMOYER, Karen; MATTHEWS, Ralph; KREWSKI, Dan. New directions - New dimensions for Environmental health research in Canada. Hamilton, McMaster Institute of Environment and Health, 1999.

EYLES, John; TAYLOR, S. Martin. Environmental health research: the meaning of measurement and the measurement of meaning. Environmental Health Program. Institute of Environment and Health. Proceedings, Working Paper 2, Environmental Epidemiology: science for society or science in society? Hamilton, Canada. p. 31-45, 1994. 
FRANK, J.W.; GIBSON, B.; MACPHERSON, M. Information needs in epidemiology: detecting the health effects of environmental chemical exposure. In C. Fowle \& et al. (Eds.), Information Needs for Risk Management, Toronto: Institute of Environmental Studies, p.129-145, 1988.

GOEHL, Thomas J. Reviews in Environmental Health, 2000. Environmental Health Perspectives, v.108 : 101 - 9, Mar, 2000. ( 1 Suppl )

HAMILTON HEALTH SCIENCE CORPORATION. Disponível em http://www.hhsc.ca. Captado em 13/10/2000 6:51.

HCWH (HEALTH CARE WITHOUT HARM). The campaign for environmentally responsible health care. Falls Church, HCWH, s.d.

HERSHKOWITZ, A Doing it better: medical waste management in Switzerland, West Germany and Sweden. In: U.S. CONFERENCE ON MUNICIPAL SOLID WASTE MANAGEMENT: SOLUTIONS FOR THE 90s, 1, Washington, 1990. Proceedings, Washington, U.S. Environmental Protection Agency, p. 1517-44, 1990.

HERTZMAN, C.; HAYES, M.; SINGER, J.; HIGHLAND, J. Upper Ottawa Street landfill site health study. Environmental Health Perspectives, v.75:173-195, 1987.

[IBGE] INSTITUTO BRASILEIRO DE GEOLOGIA E ESTATÍSTICA. Pesquisa Nacional de Saneamento Básico, PNSB-2000. São Paulo. Disponível em: $<$ http://www.ibge.gov.br/home/estatistica/populacao/condicaodevida/pnsb/lixo_coletado/lixo _coletado101.shtm> Acesso em: 16 jul. 2002.

IMPERATRIZ FONSECA, V.L. e cols. Educação ambiental: o papel da universidade. In: MASSAMBANI, O; CAMPIGLIA, S.S. (org.). Meio ambiente e desenvolvimento: FORUM. São Paulo, Universidade de São Paulo, p.111-17, 1992.

JAMES, J.; EYLES, J. Perceiving and representing both health and the environment : an exploratory investigation. Qual. Health Res., v.9, n.1: 86 - 104, Jan.1999.

JAUCHEM, J.R. \& MERRIT, J.H. The epidemiology of exposure to electromagnetic fields: an overview of the recent literature. Journal of Clinical Epidemiology, v.44, n.9: 895-906, 1991. 
JOHNSON, K.R.; BRADEN, C.R.; CAIRNS, K.L.; FIELD, K.W.; COLOMBEL, A.C.; YANG, Z.; WOODLEY, C.L.; MORLOCK, G.P.; WEBER, A.M.; BOUDREAU, A.Y.; BELL, T.A.; ONORATO, I.M.; VALWAY, S.E.; STEHR-GREEN, P.A. Transmission of Mycobacterium tuberculosis from medical waste.Comment In: JAMA. 284(13):1701-2, 2000.

KATES, R. W. Risk assessment of environmental hazard. SCOPE REPORT. Wiley, New York, n.8,1978.

KREWSKI, Daniel; BIRKWOOD, Patricia. Risk assessment and risk management. Risk Abstracts, v.4, n.1: 53-61, 1987.

LAST, J.M. Environmental health and human values. Environmental Health Program. Institute of Environment and Health. Proceedings, Working Paper 2, Environmental Epidemiology: science for society or science in society? Hamilton, Canada. p. 6-17, 1994.

LEMOS, Jureth C.; LIMA, Samuel C.; RAMOS, Leila B.M. Os impactos ambientais provocados pelo lixo hospitalar. Biosci. J., v.15, n.1: 15-28, Jun.1999.

LIEBER, Renato R.; ROMANO-LIEBER, Nicolina S. Risco, incerteza e as possibilidades de ação na saúde ambiental. Ver Bras Epidemiol., v.6, n.2: 121-134, 2003.

LIXO MUNICIPAL. Manual de gerenciamento integrado. Coord. Maria Luiza Otero D’Almeida, André Vilhena. 2.ed. São Paulo. IPT/CEMPRE, 2000. (Publicação IPT 2622).

LUGINAAH, Isaac N.; TAYLOR, S. Martin; ELLIOTT, Susan J.; EYLES, John D. A longitudinal study of the health impacts of a petroleum refinery. Social Science\&Medicine, n. 50:1155-1166, 2000.

MALAVAUD S.; MARTY, N. Infectious risk in medical offices: a reality to be fought. Presse Med., v.26, n.21: 1008-12, Jun, 21, 1997.

MASSAMBANI, O.; CAMPIGLIA, S.S. (org.) Meio ambiente e desenvolvimento: FORUM. São Paulo, Universidade de São Paulo, 1992.

MENTEK, John. Fears for health of radiation workers. The Hamilton Spectator, Local News, p.A14, Oct. 13, 2000. 
McKELVEY, M.K. Disposal of pathological waste. Dimens. Health Serv., v.68, n.7: 27-30, 1991.

MEADOWS, D.H. et al. Los limites del crescimiento. México, Col. Pop. Fondo de Cultura Economica, 1973.

MINAYO, M.C.S. O desafio do conhecimento: pesquisa qualitativa em saúde. 4. ed. São Paulo, HUCITEC, 1996. p.269.

MOREL, M.M. Processamento do lixo hospitalar. Rev.Limpeza Pública, v.39:12-4, 1992.

MORITZ, J.M. Current legislation governing clinical waste disposal. J. Hosp. Infect., v.30: 521-30, Jun, 1995. (Suppl)

NATIONAL STANDARD OF CANADA. Risk analysis requeriments and guidelines. Toronto, Canadian Standards Association. CAN/CSA-Q634-91, 1991.

NATIONAL STANDARD OF CANADA. Dependability management - Part 3: Application guide-Section 9: Risk analysis of technological systems. Toronto. Canadian Standards Association. CEI/IEC, 300-3-9:1997(a).

NATIONAL STANDARD OF CANADA. Risk management: guideline for decisionmakers. Toronto. Canadian Standards Association. CAN/CSA-Q850:1997(b).

NEUS, H; SCHUMANN, M; KOSS, G. Uncertainty analysis of quantitative risk assessment in temporally variable exposures: model observations based on biological and epidemiological risk models. Schriftenr Ver Wasser Boden Lufthyg., v.103: 140-200, 1999.

NEUTRA, R. R. Epidemiology for and with a distrustful community. Environmental Health Perspectives, v.62: 393-397, 1985.

NEELY, A,N.; MALEY, M.P.; TAYLOR, G.L. Investigation of single-use versus reusable infectious waste containers as potential sources of microbial contamination, Am J Infect Control; 31(1):13-7, 2003.

ONTARIO. Ministry of the Environment. The management of Biomedical waste in Ontario - Guideline C-4. Toronto. Queen's Printer for Ontario. 1994. 
ONTARIO. Office Consolidation. General-waste management regulation. Under the Environmental Protection Act. Regulation 347 of the revised regulations of Ontario, 1990 (as amended). Queen's Printer for Ontario. Toronto, 1998.

ORDÓÑEZ, Gonzalo A. Salud ambiental: conceptos y actividades. Rev. Panam. Salud Pública, v.7, n.3: 101-21, Mar, 2000.

OSHA (Occupational Safety and Health Administration). General Industry Standard, Federal Register. Bloodborne pathogens. Part 1910.1030, n. 56: 64175-64182, 1991.

PORTO, Marcelo F.S.; FREITAS, Carlos M. Análise de riscos tecnológicos ambientais. perspectivas para o campo da saúde do trabalhador. Cad. Saúde Pública, v.13, s.2: 21-39, 1997.

RATTNER, H. et al. Conceitos, políticas e práticas de desenvolvimento sustentável. In: MASSAMBANI, O; CAMPIGLIA, S.S (org). Meio ambiente e desenvolvimento: FORUM. São Paulo, Universidade de São Paulo. p.85-92, 1992.

ROSS, C.R. O governo federal como um defensor inadvertido da degradação do ambiente. In: Helfrich Júnior, H.W. A crise ambiental: a luta do homem para viver consigo mesmo. São Paulo, Melhoramentos/ Universidade de São Paulo, p.170-86, 1974.

ROSS, Michael W.; FERREIRA-PINTO, João. Toward a public health of situations: the recontextualization of risk. Cad. Saúde Pública, v.16, n.1: 5-15, jan., 2000.

RUNDALL, Thomas G.; DEVERS, Kelly J.; SOFAER, Shoshanna. Overview of the special supplement issue. Health Services Research, v.34, n.5: 1091-1099, Dec.1999. Part II (Special Supl.)

SÃO PAULO. Secretaria da Saúde. Secretaria do Meio Ambiente. Secretaria da Justiça e Direito à Cidadania. Resolução Conjunta n. 1 de 29 de junho de 1998. Aprova as diretrizes básicas e regulamento técnico para apresentação e aprovação do plano de gerenciamento de resíduos sólidos de serviços de saúde. Diário Oficial do Estado, São Paulo, p.56-57, 30 jun., Seção 1.

SCHULTE, P. A. Opportunities for the development and use of biomarkers. Toxicol. Lett., v. 77, n.1-3:25-9, May 1995. 
SEXTON, Ken. The role of scientific research in risk assessment and risk management decisions. Otorryngology: Head and Neck Surgery, v.106, n.6: 635-641, 1992.

SILVA, Anna E. L. D. Gerenciamento dos resíduos químicos perigosos. Rev. Arquivos da SBML, n.2: 100-103, Mai/Jun, 2000.

SILVA, A,C.; BERNARDES, R,S.; MORAES, L.R.; REIS J.D. Critérios adotados para seleção de indicadores de contaminação ambiental relacionados aos resíduos sólidos de serviços de saúde: uma proposta de avaliação. Cad. Saúde Publica; 18(5):1401-9, 2002.

SOFAER, Shoshanna. Qualitative methods: what are they and why use them? In: Devers, K.; Sofaer, S. and Rundall, T.G. Qualitative methods in health services research. Health Services Research, v.34, n.5: 1101-1118, Dec.1999. Part II (Special Supl.)

STALIKAS, C.D.; LUNAR. L.; RUBIO, S.; PEREZ-BENDITO, D. Degradation of medical X-ray film developing wastewaters by advanced oxidation processes. Water Res., v.35, n.16: 3845-56, Nov. 2001.

SESSLER, DI; BADGWELL, JM. Exposure of postoperative nurse to exhaled anesthetic gases, Anesth. Analg., v.87, n.5: 1083-8, 1998.

STERLING, Timothy; POPE, Diana S.; BISHAI, William R.; HARRINGTON, Susan; GERSHON, Robyn R.; CHAISSON, Richard E. Transmission of Mycobacterium tuberculosis from a cadaver to an embalmer. The New England Journal of Medicine, v.342, n.4: 246-248, Jan.27, 2000.

TAKAYANAGUI , A.M.M., Trabalhadores de saúde e meio ambiente: ação educativa do enfermeiro na conscientização para gerenciamento de resíduos sólidos. Tese de Doutoramento. Ribeirão Preto: Escola de Enfermagem de Ribeirão Preto, Universidade de São Paulo, 1993, 179p.

TAKAYANAGUI, A.M.M; MENDES, M.D; FERREIRA, J.B.B; SOARES, T.M.; ARAÚJO, S.P.C de; JÚNIOR, M.P. Resíduos de Serviços de Saúde ( Lixo Hospitalar)-Manual de Orientação. Ribeirão Preto. EERP/USP, SMSRP, SES-SP, 1999, 8 p.

TIEDJE, L.B; WOOD, J. Sensitizing nurses for a changing environmental health role. Public Health Nurs., v.12, n.6: 359 - 65, Dec.1995. 
THOMAS, Cynthia S. Management of infectious waste in the home care setting. Journal of Intravenous Nursing, v.20, n.4, Jul/Aug., 1997.

TORONTO. Department of Public Health. Environmental Protection Office. Determining the human health risks of environmental chemicals. Toronto. 1991.

TORONTO. Department of Public Health. Health Promotion \& Environmental Protection Office. Options to reduce mercury emissions from hospitals in the city of Toronto. Toronto Staff Report. Sept. 7, 2000. 31 p.

TRIVINÕS, A. N.S. Introdução à pesquisa em ciências sociais: a pesquisa qualitativa em educação. São Paulo, Atlas, 1995.

U.S. Department of Health and Human Services. Centers for Disease Control, Update: Universal Preautions for Prevention of transmission of human immunodeficiency virus, hepatitis B virus, and other bloodborne pathogens in health-care setting. MMWR, v.37:377$382 ; 387-388,1988$.

VENA, J.E; WEINER, J.M. Innovative multidisciplinary research in environmental epydemiology : the challenges and needs. Int. J. Occup. Med. Environ. Health, v.12, n.4: $353-70,1999$.

VRIJHEID, M. Health effects of residence near hazardous waste landfill sites: a review of epidemiology literature. Environ.Health Perspect., v.108, n.1: 101 - 12, Mar, 2000. (Suppl)

YIN, Robert K. Enhancing the quality of case studies in health care services research. Health Services Research, v.34, n.5: 1209-1224, Dec.1999 . Part II (Special Supl.)

WAKEFIELD, Sarah; ELLIOTT, Susan J. Environmental risk perception and well-being: effects of the landfill siting process in two southern Ontario communities. Social Science \& Medicine, v.50: 1139-1154. 2000.

WESTER, R. C.; MAIBACH, H. I. Understanding percutaneous absorption for occupational health and safety. Int. Journal of Occup. \& Envir. Health, v. 6, n. 2: 86-92, Apr./Jun. 2000.

WORLD HEALTH ORGANIZATION. Management of waste from hospitals: and other health care establishments. Bergen. (Euro Reports and Studies, 97). 1985. 


\section{APÊNDICES}

APÊNDICE A : Protocolo para Avaliação de Risco de Exposição por Residuos gerados em Serviços de Saúde

APÊNDICE B: Protocolo para Avaliação de Risco de Exposição por Residuos Gerados em Serviços de Saúde

APÊNDICE C - Tipos de Resíduos Produzidos no McMaster University Medical Centre - MUMC, em ordem decrescente de volume gerado, e de acordo com as diferentes áreas geradoras - Canadá, 2000. 


\section{APÊNDICE A \\ Protocolo para Avaliação de Risco de Exposição por Residuos gerados em Serviços de Saúde}

ENTREVISTA COM RESPONSÁVEIS PELO GERENCIAMENTO DOS RESÍDUOS

IDENTIFICAÇÃO DO ENTREVISTADO

Nome:

Função:

$\mathrm{IH}:$

Local:

Tempo na Função:

Tipo de preparo específico recebido:

Formação Básica:

\section{IDENTIFICAÇÃO DO ESTABELECIMENTO}

No. de leitos do Estabelecimento ou Tipo de atividade desenvolvida na área:

No. total de funcionários:

No. Médio de atendimento ambulatorial por mês ou No. Médio de atendimento/dia:

01) Como é feita a divisão dos diferentes setores do trabalho?

ENTREVISTA

02) Qual é a produção de RSS/dia/semana/mês, de acordo com as diferentes fontes geradoras?

03) Qual é o volume de produção dos diferentes tipos de RSS/dia ou por semana?

04) Você vê algum tipo de problema no manuseio e descarte dos RSS dentro do serviço? Se afirmativo, em qual etapa do seu processamento e de que tipo?

Separação

Acondicionamento

Coleta interna

Transporte interno

Armazenamento interno

Apresentação à coleta externa

Coleta e Transporte Externo

Tratamento

Destinação Final:

Outros:

05) Já foram tomadas medidas para corrigir esses problemas? SIM ( ) NÃO ( )

Quais?

06) Você encontrou dificuldades para isso?

SIM ( ) NÃO ( )

Quais?

07) Você tem alguma proposta para solução do(s) problema(s) citados?

08) Na sua opinião, há nessa área situação de risco de exposição do pessoal da saúde a agentes poluidores?

$\operatorname{SIM}($ ) NÃO ( ) Quais?

Pessoas mais afetadas:

Assinatura: Data: 


\section{APÊNDICE B \\ Protocolo para Avaliação de Risco de Exposição por Resíduos Gerados em Serviços de Saúde}

OBSERVAÇÃO SISTEMATIZADA

$\underline{\text { Identificação }}$

ÁREA: DO HOSPITAL: Data

Localização: Tipo de atendimento:

Média de atendimento geral da área por semana:

No. Total de funcionários:

\section{Observação do Processamento dos Resíduos na Área}

Quanto `a Segregação dos resíduos:

01) Os resíduos estão separados segundo as recomendações legais do país?

\section{SIM ( ) NÃO ( )}

Se não, descreva:

02) É possível perceber que as embalagens contém:

2a - Material Biológico?

$\operatorname{SIM}($ ) NÃO ( )

$2 \mathrm{~b}$ - Sangue e Hemoderivados?

SIM ( ) NÃO ( )

2c - Resíduos Cirúrgicos e anátomo-patológicos?

SIM ( ) NÃO ( )

2d - Resíduos Perfurocortantes?

SIM ( ) NÃO ( )

2e - Animais ou Similares?

SIM ( ) NÃO ( )

2f - Outros (especificar):

Quanto ao Acondicionamento:

03) Qual é o tipo de acondicionamento utilizado?

Descreva:

04) Há diferenciação de cor das embalagens?

SIM ( ) NÃO ( )

Descreva:

05) As embalagens são identificadas segundo a origem e o tipo de conteúdo?

SIM ( ) NÃO ( )

Se não, descreva:

06) Os sacos ou outro tipo de embalagem são ocupados, no máximo, até 2/3 de sua capacidade e estão fechados?

$\operatorname{SIM}($ ) NÃO ( )

Descreva:

07) Os resíduos infectantes são duplamente acondicionados em sacos plásticos?

$\operatorname{SIM}($ ) NÃO ( )

Descreva: 
08) Os resíduos perfurocortantes são embalados em recipientes rígidos e íntegros?

SIM ( ) NÃO ( )

Descreva o tipo e as condições observadas:

Quanto à Coleta, Transporte e Armazenamento Interno:

09) O serviço possui um local exclusivo e protegido para o armazenamento interno dos resíduos?

SIM ( ) NÃO ( )

Descreva:

10) Este local é de fácil acesso ao transporte interno?

SIM ( ) NÃO ( )

Descreva:

Quanto à Coleta, Transporte e Apresentação dos resíduos à Coleta Externa

11) Como são transportados os resíduos do local de armazenamento interno até o local de armazenamento para coleta externa?

Descreva:

12) É de fácil acesso à coleta externa?

SIM ( ) NÃO ( )

Descreva:

13) Situa-se longe de cozinha, dispensa e outros locais acessíveis à população e vetores?

SIM ( ) NÃO ( )

Descreva:

14) Descreva as condições de higiene e limpeza, segundo:

14a - Limpeza e desinfecção geral diária:

$14 \mathrm{~b}$ - Pisos e paredes:

$14 \mathrm{c}$ - Drenagem interna:

14d - Temperatura local:

14e - Existência de recipientes contenedores:

15) Qual o fluxo dos RSS na área?

Descreva:

16) Não havendo local específico, onde é colocado o lixo?

17) Qual a freqüência de recolhimento pela coleta externa? Que tipo de empresa é responsável por este serviço?

18) Quantos sacos ou outro tipo de embalagem, aproximadamente, são recolhidos em cada coleta externa e qual a capacidade de cada um dos sacos? Ou qual o volume de resíduo produzido diariamente na área?

Quanto ao Tratamento e Destinação Final: 
19) O serviço conta com algum tipo de tratamento dos RSS no local?

Descreva:

20) O serviço conta com sistema de reciclagem? Descreva:

21) Para onde são encaminhados os RSS do Serviço?

22) Qual o tipo de tratamento recebido nesse local de encaminhamento?

23) Qual o tipo de destinação final dada para os RSS?

24) Qual a sua localização?

25) Observações feitas pelo funcionário do serviço que acompanhou a visita de observação:

26) Impressões do observador:

Término da observação: Horas Ass. 
APÊNDICE C - Tipos de Residuos Produzidos no McMaster University Medical Centre - MUMC, em ordem decrescente de volume gerado, e de acordo com as diferentes áreas geradoras - Canadá, 2000. Área do Hospital Entrevistado

\begin{tabular}{|c|c|c|c|c|c|c|c|c|c|c|}
\hline Tipos de Resíduos Áreas & $\begin{array}{l}\text { Centro } \\
\text { Cirúrgico }\end{array}$ & $\begin{array}{l}\text { Laboratório } \\
\text { de Patologia }\end{array}$ & Farmácia & $\begin{array}{l}\text { Laboratório } \\
\text { Central }\end{array}$ & Enfermarias & Emergência & $\begin{array}{l}\text { Unidade de } \\
\text { Assistência à } \\
\text { Família }\end{array}$ & $\begin{array}{l}\text { Salas de } \\
\text { Parto }\end{array}$ & Radiologia & $\begin{array}{l}\text { Medicina } \\
\text { Nuclear }\end{array}$ \\
\hline $\begin{array}{l}\text { Não anatômicos/não } \\
\text { citotóxicos (cortantes ou } \\
\text { não cortantes) }\end{array}$ & & & & & & & & & & \\
\hline $\begin{array}{l}\text { Anatômicos / Biológicos } \\
\text { Perigoso * }\end{array}$ & & & & & & & & & & \\
\hline $\begin{array}{l}\text { Biológicos citotóxicos } \\
\text { Perigosos } * *\end{array}$ & & & & & & & & & & \\
\hline $\begin{array}{l}\text { Farmacêuticos não } \\
\text { Perigosos }\end{array}$ & & & & & & & & & & \\
\hline $\begin{array}{l}\text { Farmacêuticos Perigosos } \\
\text { (Classe 261A, B, I, L) }\end{array}$ & & & & & & & & & & \\
\hline Narcóticos & & & & & & & & & & \\
\hline Recicláveis & & & & & & & & & & \\
\hline Comuns & & & & & & & & & & \\
\hline Confidenciais & & & & & & & & & & \\
\hline $\begin{array}{l}\text { Perigosos (Tintas, } \\
\text { Pesticidas, Químicos) }\end{array}$ & & & & & & & & & & \\
\hline Radiativos & & & & & & & & & & \\
\hline
\end{tabular}




\section{ANEXOS}

ANEXO A: CONSENT FORM FOR ATTEND TO ENVIRONMENT AND HEALTH STUDY

ANEXO B: BROCHURA AUXILIAR DO CHECK-LIST 


\author{
ANEXO A \\ CONSENT FORM FOR ATTEND TO ENVIRONMENT AND HEALTH STUDY \\ TITLE OF PROJECT: ENVIRONMENTAL RISK ASSESSMENT IN THE \\ MANAGEMENT OF BIOMEDICAL WASTE AT MUMC \\ PRINCIPAL INVESTIGATOR: Dr. Angela Maria Magosso Takayanagui \\ McMaster Institute of Environment and Health \\ OTHER INVESTIGATORS: John Eyles \\ Susan Elliott
}

This is to certify that I, have been given the following information with respect to my participation as a volunteer in a program of investigation under the supervision of Dr. Angela M.M.Takayanagui.

\title{
PURPOSE OF THE STUDY:
}

The objective of the present study is to improve the research in environmental health, especially with respect to environmental risk assessment in the management of biological waste. In order to get better understanding of this process interviews will be make with leaders on the main points where this waste is produced at the McMaster University Medical Centre - MUMC, Canada, aiming to plan actions to be applied in a similar situation in Brazil.

\section{PROCEDURES TO BE FOLLOWED:}

According to the purpose of this study, the interviewers will be asked about the kind of BW generated and the steps of the BW Management in each (their) ward area at the MUMC on by their responsibility.

\section{DISCOMFORTS AND RISKS:}

There is not any kind of foreseeable risks or discomforts to the subjects.

\section{BENEFITS TO ME:}

The benefits are supposed to society. I'm not supposed to have been given any financial compensation by participating in this study.

VOLUNTARY PARTICIPATION: 
I understand that my participation in this study is voluntary, and that my withdraw from this study may occur at any time by notifying the investigator. My withdraw from this study or my refusal to participate will be accept by the investigator, and it will not (ensure ) affect in any consequence / or it will bring no (ensure) any personal consequence for me.

\section{LOCAL AND TIME DURATION OF THE PROCEDURES AND STUDY:}

The subjects are supposed to spend not more than 30 minutes for the enterview in their work area. They could be asked for some complementary information after the interview if necessary. This study will be (ongoing) doing during September and October, 2000 at the McMaster University Medical Centre.

\section{STATEMENT OF CONFIDENTIALITY:}

All records associated with my participation in the study will be subject to the usual confidentiality standards applicable to research and in the event of any publication resulting from the research no personally identifiable information will be disclosed.

NAME: DATE: 
ANEXO B

BROCHURA AUXILIAR DO CHECK-LIST 